\title{
Hybrid Direct Carbon Fuel Cell Anode Processes Investigated Using a 3-electrode Half-cell Setup
}

\author{
L. Deleebeeck ${ }^{\mathrm{a}, ~ *}$, A. Arenillas ${ }^{\mathrm{b}}$, J.A. Menendez ${ }^{\mathrm{b}}$, and K. Kammer Hansen ${ }^{\mathrm{a}, 1}$ \\ ${ }^{a}$ Department of Energy Conversion and Storage, Danish Technical University (DTU), Ris $\varnothing$ \\ Campus, Frederiksborgvej 399, PO Box 49, DK-4000 Roskilde, Denmark \\ ${ }^{\mathrm{b}}$ Instituto Nacional del Carbon (CSIC), c/ Francisco Pintado Fe 26, 33011 Oviedo, Spain \\ * Corresponding author: ldel@dtu.dk \\ ${ }^{1}$ kkha@dtu.dk, (45) 46775835
}

\begin{abstract}
A 3-electrode half-cell setup consisting of a yttria-stabilized zirconia (YSZ) electrolyte support was employed to investigate the chemical and electrochemical processes occurring in the vicinity of a model hybrid direct carbon fuel cell (HDCFC) anode (Ni-YSZ) in contact with a molten carbonalkali carbonate slurry. Electrochemical testing, cyclic voltammetry (CV) and electrochemical impedance spectroscopy (EIS), with and without the Ni-YSZ layer highlighted the promotional effect of the Ni-YSZ anode layer, and revealed the contributions of $\mathrm{Ni} / \mathrm{NiO}$, and potentially $\mathrm{K} / \mathrm{K}_{2} \mathrm{O}$, redox couple(s). Treated anthracite and bituminous coals, as well as carbon black, were tested, revealing similar open circuit potential and activation energies in mixed $96-4$ vol\% $\mathrm{N}_{2}-\mathrm{CO}_{2}$ and $50-$ 50 vol\% $\mathrm{CO}-\mathrm{CO}_{2}$ environments between 700 and $800{ }^{\circ} \mathrm{C}$. Bituminous coal showed the highest activity, likely associated to a high $\mathrm{O} / \mathrm{C}$ ratio and hydrogen content. Based on acquired data, a reaction scheme was proposed for processes at the working electrode, including the role of bubble formation in the vicinity of the electrochemically active solid/molten medium interface.
\end{abstract}

Keywords: Direct carbon fuel cell (DCFC), half-cell, cyclic voltammetry (CV), anthracite, bituminous coal, carbon monoxide, carbon dioxide 


\section{Introduction}

High temperature direct carbon fuel cells (DCFCs) include molten carbonate (MCFC) and solid oxide fuel cells (SOFC) with solid carbon fuel, such as coal, included in the anode chamber. SOFCtype DCFCs have the advantage of relatively simple infrastructure requirements (solid substrate, air supply to the cathode), but suffer from contact issues between the solid fuel and the electrochemically active surface at the anode. MCFC-type DCFCs have the advantage of enhanced and sustained contact between the solid fuel and molten electrolyte, but suffer from corrosion issues and increased infrastructural constraints (containment of a molten medium, air and $\mathrm{CO}_{2}$ supply to the cathode) [1]. Hybridization of these two DCFC concepts aims to overcome the shortcomings while maintaining the advantages of each. A hybrid DCFC (HDCFC) consists of a SOFC with a molten mixture of carbon and alkali carbonate included in the anode chamber, such that infrastructural advantages (reduced corrosion issues at, and air supply only to, the cathode) and fuel/electrolyte contact enhancement are simultaneously achieved [2-3].

DCFC performance is typically limited by processes occurring at the anode [2]. The presence of the carbon-carbonate slurry in contact with the anode layer of a SOFC (typically Ni-yttria-stabilized zirconia (YSZ)) makes for a complex system when investigating HDCFC performance. To help elucidate HDCFC anode processes, a 3-electrode, single atmosphere half-cell configuration has been developed [4-5]. Previous 3-electrode half-cell studies of DCFCs [6-23] have been based on a MCFC-type DCFC design developed by Vutetakis et al. (1987) [6]. That setup consists of a containment vessel filled with molten alkali carbonates, into which working (WE), counter (CE) and reference electrode (RE) are immersed. Solid carbon is introduced in either monolithic or dispersed form, typically 1-15 wt\% carbon in molten carbonate [6]. Monolithic, sacrificial (i.e., consumed during experimentation) dense rods of carbon (e.g., graphite [7]) are employed as both WE and fuel source. Electrochemical data has been acquired using linear sweep voltammetry 
(LSV), where potential was typically measured against $\mathrm{Au}$ in a 33:67 vol\% $\mathrm{O}_{2} / \mathrm{CO}_{2}$ atmosphere [6]. MCFC-type DCFC single-atmosphere 3-electrode setups, detailed in Table 1, have been employed to investigate a variety of experimental variables, including: coal rank [9], coal pre-treatments [10], carbon fuel properties [13], carbon loading [6], carbonate melt additives [19, 20], stirring rate [6], temperature [8], time [23] and atmosphere composition [6, 11, 12]. These setups have also been employed to explore DCFC reaction mechanisms [22], and to measure current at fixed potential in order to calculate activation energies $[8,18]$. 
Table 1. Single atmosphere 3-electrode studies on DCFCs

\begin{tabular}{|c|c|c|c|c|c|c|c|c|}
\hline Researcher & Electrolyte $^{\mathrm{a}}$ & Carbon $^{\mathrm{b}}$ & $\begin{array}{l}\text { C loading }(\mathrm{wt} \%) / \\
\text { Atmosphere }^{\mathrm{d}}\end{array}$ & $\mathrm{WE}^{\mathrm{e}}$ & $R E^{f}$ & $\mathrm{CE}^{\mathrm{g}}$ & $\begin{array}{l}\mathrm{T}^{\mathrm{h}} \\
\left({ }^{\circ} \mathrm{C}\right)\end{array}$ & Ref. \\
\hline $\begin{array}{l}\text { DG } \\
\text { Vutetakis }\end{array}$ & $\begin{array}{l}\text { 32.1-34.5- } \\
\text { 33.4 Li-K-Na }\end{array}$ & $\begin{array}{l}\text { Coal, } \\
\text { coal } \\
\text { char, G }\end{array}$ & $\begin{array}{l}1-15 / \mathrm{CO}_{2}, 3 \% \\
\mathrm{CO}_{2}-\mathrm{N}_{2}\end{array}$ & $\begin{array}{l}\mathrm{Au} \\
\text { or } \mathrm{G}\end{array}$ & $\begin{array}{l}\mathrm{Au} / 1: 2 \\
\mathrm{O}_{2}: \mathrm{CO}_{2}\end{array}$ & $\mathrm{G}$ & 700 & 6 \\
\hline K Hemmes & $62-38 \mathrm{Li}-\mathrm{K}$ & $\mathrm{G}$ & Monolithic/ $\mathrm{CO}_{2}$ & $\mathrm{G}$ & $\mathrm{SOR}^{\mathrm{i}}$ & & $\begin{array}{l}600- \\
750\end{array}$ & 7 \\
\hline \multirow[t]{3}{*}{$\overline{\text { Z Zhu }}$} & $\begin{array}{l}\text { 32-34-34 Li- } \\
\text { Na-K }\end{array}$ & $\begin{array}{l}\mathrm{AC}, \\
\mathrm{N} 220, \\
\mathrm{~N} 660, \mathrm{G}\end{array}$ & $1-10 / \mathrm{Ar}$ & $\mathrm{Au}$ & $\begin{array}{l}\mathrm{Au} / 5: 2 \\
\text { air: } \mathrm{CO}_{2}\end{array}$ & $\begin{array}{l}\mathrm{Au} / 5: 2 \\
\text { air: } \mathrm{CO}_{2}\end{array}$ & $\begin{array}{l}600- \\
800\end{array}$ & 8 \\
\hline & $\begin{array}{l}\text { 32-34-34 Li- } \\
\text { Na-K }\end{array}$ & $\begin{array}{l}\text { Coal, } \\
\text { AC }\end{array}$ & $5 / \mathrm{Ar}$ & $\mathrm{Au}$ & $\begin{array}{l}\mathrm{Au} / 5: 2 \\
\text { air: } \mathrm{CO}_{2}\end{array}$ & $\begin{array}{l}\mathrm{Au} / 5: 2 \\
\text { air: } \mathrm{CO}_{2}\end{array}$ & $\begin{array}{l}600- \\
800\end{array}$ & 9 \\
\hline & $\begin{array}{l}\text { 32-34-34 Li- } \\
\text { Na-K }\end{array}$ & coal & $5 / \mathrm{Ar}$ & $\mathrm{Au}$ & $\begin{array}{l}\mathrm{Au} / 5: 2 \\
\text { air:CO2 }\end{array}$ & $\begin{array}{l}\mathrm{Au} / 5: 2 \\
\text { air:CO2 }\end{array}$ & $\begin{array}{l}600- \\
800\end{array}$ & 10 \\
\hline $\begin{array}{l}\text { YuD } \\
\text { Varlamov }\end{array}$ & $38-62 \mathrm{Li}-\mathrm{K}$ & Coal, G & $\begin{array}{l}\text { Monolithic/O } 2^{-} \\
\mathrm{CO}_{2}\end{array}$ & $\bar{G}$ & $\begin{array}{l}\mathrm{Pt} / 1: 2 \\
\mathrm{O}_{2}: \mathrm{CO}_{2}\end{array}$ & steel & $\begin{array}{l}700- \\
750\end{array}$ & 11 \\
\hline JR Selman & 62-38 Li-K & $\mathrm{G}$ & $\begin{array}{l}\text { Monolithic/ } \mathrm{CO}_{2}, \\
5 \% \mathrm{CO}_{2}-\mathrm{N}_{2}\end{array}$ & $\bar{G}$ & $\begin{array}{l}\mathrm{Au} / 1: 2 \\
\mathrm{O}_{2}: \mathrm{CO}_{2}\end{array}$ & $\mathrm{Au}$ & 650 & 12 \\
\hline \multirow[t]{4}{*}{ D Kim } & $62-38 \mathrm{Li}-\mathrm{K}$ & $\begin{array}{l}\text { Coal, } \\
\text { wastes }\end{array}$ & $10 / \mathrm{He}$ & $\mathrm{Ag}$ & $\begin{array}{l}\mathrm{Ag} / 1: 2 \\
\mathrm{O}_{2}: \mathrm{CO}_{2}\end{array}$ & $\begin{array}{l}\mathrm{Ag} / 1: 2 \\
\mathrm{O}_{2}: \mathrm{CO}_{2}\end{array}$ & $\begin{array}{l}650- \\
750\end{array}$ & 13 \\
\hline & $62-38 \mathrm{Li}-\mathrm{K}$ & $\begin{array}{l}\text { Coal, } \\
\text { biochar }\end{array}$ & $5 / \mathrm{He}$ & $\mathrm{Ag}$ & $\begin{array}{l}\mathrm{Ag} / 7: 3 \\
\text { air: } \mathrm{CO}_{2}\end{array}$ & $\begin{array}{l}\mathrm{Ag} / 7: 3 \\
\text { air: } \mathrm{CO}_{2}\end{array}$ & $\begin{array}{l}650- \\
750 \\
\end{array}$ & 13 \\
\hline & 62-38 Li-K & $\begin{array}{l}\text { Coal, } \\
\text { coal char }\end{array}$ & $10 / \mathrm{Ar}$ & $\mathrm{Ag}$ & $\begin{array}{l}\mathrm{Ag} / 1: 2 \\
\mathrm{O}_{2}: \mathrm{CO}_{2}\end{array}$ & $\begin{array}{l}\mathrm{Ag} / 1: 2 \\
\mathrm{O}_{2}: \mathrm{CO}_{2}\end{array}$ & 700 & 15 \\
\hline & 62-38 Li-K & $\begin{array}{l}\text { Coal, } \\
\text { coal char }\end{array}$ & $10 / \mathrm{Ar}$ & $\mathrm{Au}$ & $\begin{array}{l}\mathrm{Au} / 1: 2 \\
\mathrm{O}_{2}: \mathrm{CO}_{2}\end{array}$ & $\begin{array}{l}\mathrm{Au} / 1: 2 \\
\mathrm{O}_{2}: \mathrm{CO}_{2}\end{array}$ & 700 & 16 \\
\hline \multirow[t]{4}{*}{ D Cao } & $\begin{array}{l}32-68 \mathrm{Li}-\mathrm{K} \\
\pm \mathrm{M}_{\mathrm{x}} \mathrm{O}_{\mathrm{y}}\end{array}$ & $\mathrm{G}$ & Monolithic/ $\mathrm{N}_{2}$ & $\bar{G}$ & $\begin{array}{l}\mathrm{Au} / 1: 2 \\
\mathrm{O}_{2}: \mathrm{CO}_{2}\end{array}$ & $\mathrm{G}$ & $\begin{array}{l}650- \\
850\end{array}$ & 17 \\
\hline & 32-68 Li-K & $\begin{array}{l}\mathrm{G} \pm \\
\mathrm{CeO}_{2}\end{array}$ & Monolithic/ $\mathrm{N}_{2}$ & $\mathrm{G}$ & $\begin{array}{l}\mathrm{Au} / 1: 2 \\
\mathrm{O}_{2}: \mathrm{CO}_{2}\end{array}$ & $\mathrm{G}$ & $\begin{array}{l}600- \\
750\end{array}$ & 18 \\
\hline & $\begin{array}{l}\text { 32-34-34 Li- } \\
\mathrm{Na}-\mathrm{K} \pm \\
\mathrm{CsVO}_{3-} \\
\mathrm{MoO}_{3} \\
\end{array}$ & $\mathrm{G}$ & Monolithic/ $\mathrm{N}_{2}$ & $\bar{G}$ & $\begin{array}{l}\mathrm{Au} / 1: 2 \\
\mathrm{O}_{2}: \mathrm{CO}_{2}\end{array}$ & $\mathrm{Au}$ & $\begin{array}{l}550- \\
800\end{array}$ & 19 \\
\hline & $\begin{array}{l}62-38 \mathrm{Li}-\mathrm{K} \\
\pm \mathrm{S}\end{array}$ & $\mathrm{G}$ & Monolithic/ $\mathrm{N}_{2}$ & $\begin{array}{l}\mathrm{Au} \\
\text { or } \mathrm{G}\end{array}$ & $\begin{array}{l}\mathrm{Au} / 1: 2 \\
\mathrm{O}_{2}: \mathrm{CO}_{2}\end{array}$ & $\mathrm{G}$ & $\begin{array}{l}600- \\
700\end{array}$ & 20 \\
\hline \multirow[t]{2}{*}{ SW Donne } & $\begin{array}{l}43.5-31.5-25 \\
\text { Li-Na-K }\end{array}$ & $\begin{array}{l}\mathrm{G} \pm \\
\text { clays }\end{array}$ & Monolithic/ $\mathrm{CO}_{2}$ & $\mathrm{G}$ & $\mathrm{G} / \mathrm{CO}_{2}$ & $\mathrm{G}$ & 500 & 21 \\
\hline & $\begin{array}{l}43.5-31.5-25 \\
\text { Li-Na-K }\end{array}$ & Coal, G & Monolithic/CO $\mathrm{CO}_{2}$ & $\bar{G}$ & $\mathrm{G} / \mathrm{CO}_{2}$ & $\mathrm{G}$ & 500 & 22 \\
\hline $\begin{array}{l}\mathrm{H} \\
\text { Watanabe }\end{array}$ & $\begin{array}{l}11.2-44.4- \\
44.4 \mathrm{Li}-\mathrm{Na}-\mathrm{K}\end{array}$ & $\mathrm{AC}$ & $1-3 / \mathrm{Ar}$ & $\mathrm{Au}$ & $\begin{array}{l}\mathrm{Au} / 1: 2 \\
\mathrm{O}_{2}: \mathrm{CO}_{2}\end{array}$ & $\mathrm{Au}$ & 800 & 23 \\
\hline $\begin{array}{l}\text { KK } \\
\text { Hansen }\end{array}$ & $\begin{array}{l}62-38 \mathrm{Li}-\mathrm{K}+ \\
\text { YSZ }\end{array}$ & $\begin{array}{l}\text { Coal, } \\
\text { C black }\end{array}$ & $\begin{array}{l}4: 1 \mathrm{wt} \% \\
\mathrm{C}: \mathrm{CO}_{3} / \mathrm{N}_{2}-\mathrm{CO}_{2} \text {, } \\
\mathrm{CO}-\mathrm{CO}_{2}\end{array}$ & $\begin{array}{l}\mathrm{Au} \\
\text { or } \\
\mathrm{Ni}- \\
\mathrm{YSZ}\end{array}$ & $\begin{array}{l}\mathrm{Pt} / \mathrm{CO}- \\
\mathrm{CO}_{2}\end{array}$ & $\begin{array}{l}\mathrm{Pt} / \mathrm{CO}- \\
\mathrm{CO}_{2}\end{array}$ & $\begin{array}{l}700- \\
800\end{array}$ & $\begin{array}{l}\text { This } \\
\text { study }\end{array}$ \\
\hline
\end{tabular}


${ }^{a}$ Composition of the molten carbonate electrolyte, written as (mol\% alkali metals) ${ }_{2} \mathrm{CO}_{3}$ (e.g., (62-38 mol\% $\mathrm{Li}-\mathrm{K})_{2} \mathrm{CO}_{3}$

${ }^{\mathrm{b}}$ Carbon species tested, including various types of coal (anthracite, bituminous, and sub-bituminous), activated carbon $(\mathrm{AC})$, carbon black (C black = carbon black acetylene, N330 and N660 (furnace blacks)), pyrolyzed and carbonized coal (coal char), pyrolyzed biomass (biochar), solid carbon derived from pyrolyzed plastic and paper-based wastes (wastes) and graphite (G)

${ }^{\mathrm{c}}$ Loading of solid carbon in alkali carbonate, given in wt $\%$ of dispersed carbon in excess carbonate. Where 'monolithic' denotes the introduction of a dense rod of carbon into the melt, serving as both fuel and WE

${ }^{d}$ Atmosphere in the vicinity of the WE

${ }^{\mathrm{e}}$ Material composition of the WE, working atmosphere

${ }^{\mathrm{f}}$ Material composition of the RE and surrounding atmosphere, against which the potential is measured (e.g., $\mathrm{mV}$ vs. $\left.\mathrm{Au} / \mathrm{CO}_{3}{ }^{2-} / 1: 2 \mathrm{O}_{2}: \mathrm{CO}_{2}\right)$

${ }^{\mathrm{g}}$ Material composition of the CE and surrounding atmosphere, where no gas specified indicates the CE is not surrounded by a specifically introduced gas, but is present in the working atmosphere with the WE

${ }^{\mathrm{h}}$ Temperature range investigated

${ }^{\mathrm{i}}$ standard oxygen reference (SOR)

In the current investigation, a single-atmosphere HDCFC 3-electrode half-cell setup is employ, which differs from previous setups [6-23] most significantly through the inclusion of the YSZ solid oxide electrolyte and use of a combination of reference electrodes which are not immersed in the carbon-carbonate melt (Table 1). This setup is employed to investigate, using cyclic voltammetry (CV) and electrochemical impedance spectroscopy (EIS), the influence of the anode layer (NiYSZ), carbon fuel (carbon black, coal), temperature $\left(700-800^{\circ} \mathrm{C}\right)$, and working atmosphere (mixed $\mathrm{N}_{2}-\mathrm{CO}_{2}$ or $\mathrm{CO}-\mathrm{CO}_{2}$ ) on HDCFC anode chamber chemical and electrochemical processes. 


\section{Experimental}

Electrolyte-supported 3-electrode pellets were prepared and mounted in a single-atmosphere electrochemical testing setup as described in Deleebeeck et al. (2014) [4]. The setup for one halfcell is shown schematically in Fig. 1. Half-cells were prepared both with and without the NiO-YSZ WE layer. Both setups were equipped with a Au mesh current collector. Data was acquired with the Ni-YSZ anode layer unless stated otherwise. Carbon fuels utilized include carbon black acetylene (C black, 99.9\%, Alfa Aesar) and milled and treated anthracite (AIII) and bituminous coals from Spanish basins (B-I and B-II). All coals were milled to $<75 \mu \mathrm{m}$ particle size. Samples of milled anthracite and bituminous coals were de-mineralized (AIII-MD and B-I-MD) as described in [3]. Milled and de-mineralized anthracite samples were heat treated in $\mathrm{N}_{2}\left(800{ }^{\circ} \mathrm{C} / 2 \mathrm{hrs}\right)$, producing a carbonized (AIII-C) sample. The proximate and ultimate analysis of coals samples, determined as in [3], are given in Table 2.

Carbon fuel was mixed with $(62-38 \mathrm{wt} \% \mathrm{Li}-\mathrm{K})_{2} \mathrm{CO}_{3}$ as 4:1 wt $\%$ carbon:carbonate. Two 3-electrode half-cells loaded with solid carbon-carbonate were simultaneously mounted into a ceramic cell holder, and sealed inside an alumina vessel, which was placed inside a furnace. The ceramic cell holder was equiped with an oxygen partial pressure sensor, which reported $\mathrm{P}_{\mathrm{O} 2}$ equivalent electromagnetic force (in $\mathrm{mV}$ ) of the working atmopshere $\left(\mathrm{CO}-\mathrm{CO}_{2}\right)$ vs. air. Data was acquired on 2-10 replicate samples for each configuration. 


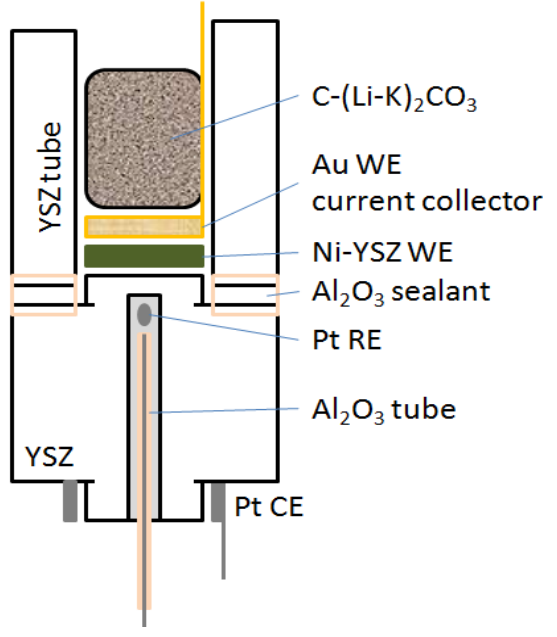

Fig. 1 - Experimental setup. 3-electrode HDCFC half-cell, with a WE $7.4 \mathrm{~mm}$ in diameter.

Half-cells were heated to $800{ }^{\circ} \mathrm{C}\left(180{ }^{\circ} \mathrm{C} / \mathrm{hr}\right)$ in $\mathrm{N}_{2}(5.76 \mathrm{~L} / \mathrm{hr})$. Following reduction of $\mathrm{NiO}(800$ $\left.{ }^{\circ} \mathrm{C} / \sim 30 \mathrm{~min}\right)$, a mixture of $96-4 \mathrm{vol} \% \mathrm{~N}_{2}-\mathrm{CO}_{2}(2.3$ or $6 \mathrm{~L} / \mathrm{hr}$ total flow) was introduced, and temperature was ramped to operating temperature $\left(700-800{ }^{\circ} \mathrm{C}\right)$. EIS data was obtained using a Solartron 1250/1287 potentiostate/frequency response analyzer combination. Data was acquired without applied current $(\mathrm{I}=0$ ), over the frequency range 65,000 to $0.05 \mathrm{~Hz}$ (descending, 6 pts/decade), and at an amplitude of $30 \mathrm{mV}$. Nyquist plots were fitted using a model circuit consisting of a resistor (series resistance, Rs) connected in series with two resistor-constant phase element units (RQ, in parallel), shown inset in Fig. 2(b). Polarization resistance (Rp) values were calculated from the sum of high (HF) and low frequency (LF) resistors (from RQ units). As the electrochemically active surface area near the WE was felt to be poorly defined and dynamic, resistance values have not been area corrected and are given in $\Omega$.

$\mathrm{CV}$ data was acquired between $\pm 500 \mathrm{mV}$ vs. the internal $\mathrm{RE}\left(\mathrm{Pt}\right.$ in $\mathrm{CO}-\mathrm{CO}_{2}$ ), scanned at 3-15 $\mathrm{mV} / \mathrm{s}$, although $10 \mathrm{mV} / \mathrm{s}$ was employed unless stated otherwise. Potential measured against the internal $\mathrm{RE}$ is termed potential difference $\left(\Delta \mathrm{E}, \mathrm{mV}\right.$ vs. $\left.\mathrm{Pt} / \mathrm{CO}-\mathrm{CO}_{2}\right)$. Open circuit potential $(\mathrm{OCP})$ was monitored galvanostatically $(\mathrm{I}=0)$ vs. $\mathrm{Pt} / \mathrm{CO}-\mathrm{CO}_{2}$, and $\mathrm{OCP}$ vs. Pt/air was calculating using 
$\mathrm{P}_{\mathrm{O} 2}$ sensor data. OCP ( $\mathrm{mV}$ vs. Pt/air) values are reported as the absolute value of the potential measured with respect to a Pt electrode in air at atmospheric pressure. Potentials measured with respect to the OCP are termed overpotential ( $\eta, \mathrm{mV}$ vs. OCP). Cell performance was measured as a function of temperature $\left(700-800{ }^{\circ} \mathrm{C}\right.$ ) and working atmosphere (4-100 vol\% $\mathrm{CO}_{2}$ in $\left.\mathrm{N}_{2}-\mathrm{CO}_{2}\right)$ using $\mathrm{CV}$ and EIS, while performance as a function of temperature in $50-50 \mathrm{vol} \% \mathrm{CO}-\mathrm{CO}_{2}(2.3 \mathrm{~L} / \mathrm{hr}$ total flow) was investigated using CV.

\section{Results}

\subsection{Ni-YSZ WE layer}

$\mathrm{CV}$ and EIS data was acquired in $96-4 \mathrm{~N}_{2}-\mathrm{CO}_{2}$ between 700 and $800{ }^{\circ} \mathrm{C}$ for half-cells fueled with carbon black both with (Fig. 2) and without (Fig. 3) a Ni-YSZ layer at the WE. CV data acquired in the presence of Ni-YSZ evidenced a peak in the forward $\left(\Delta \mathrm{E}=0 \rightarrow 500 \mathrm{mV}\right.$ vs. $\left.\mathrm{Pt} / \mathrm{CO}-\mathrm{CO}_{2}\right)$ sweep, which was absent without the Ni-YSZ layer (Fig. 3(a)). This anodic $(\Delta \mathrm{E}>0)$ peak has been attributed to the $\mathrm{Ni} / \mathrm{NiO}$ reduction/oxidation (redox) couple [4]. In contrast, when carbon black was placed in direct contact with the YSZ electrolyte (no Ni-YSZ layer), a peak was seen on the return $\left(\Delta \mathrm{E}=500 \rightarrow-500 \mathrm{mV}\right.$ vs. $\left.\mathrm{Pt} / \mathrm{CO}-\mathrm{CO}_{2}\right)$ sweep. This cathodic $(\Delta \mathrm{E} \leq 0)$ peak was observed with a half-potential $\left(\mathrm{E}_{1 / 2}\right)$ relatively close in magnitude to the OCP $(\sim 1100 \mathrm{mV}$ vs. Pt/air). 

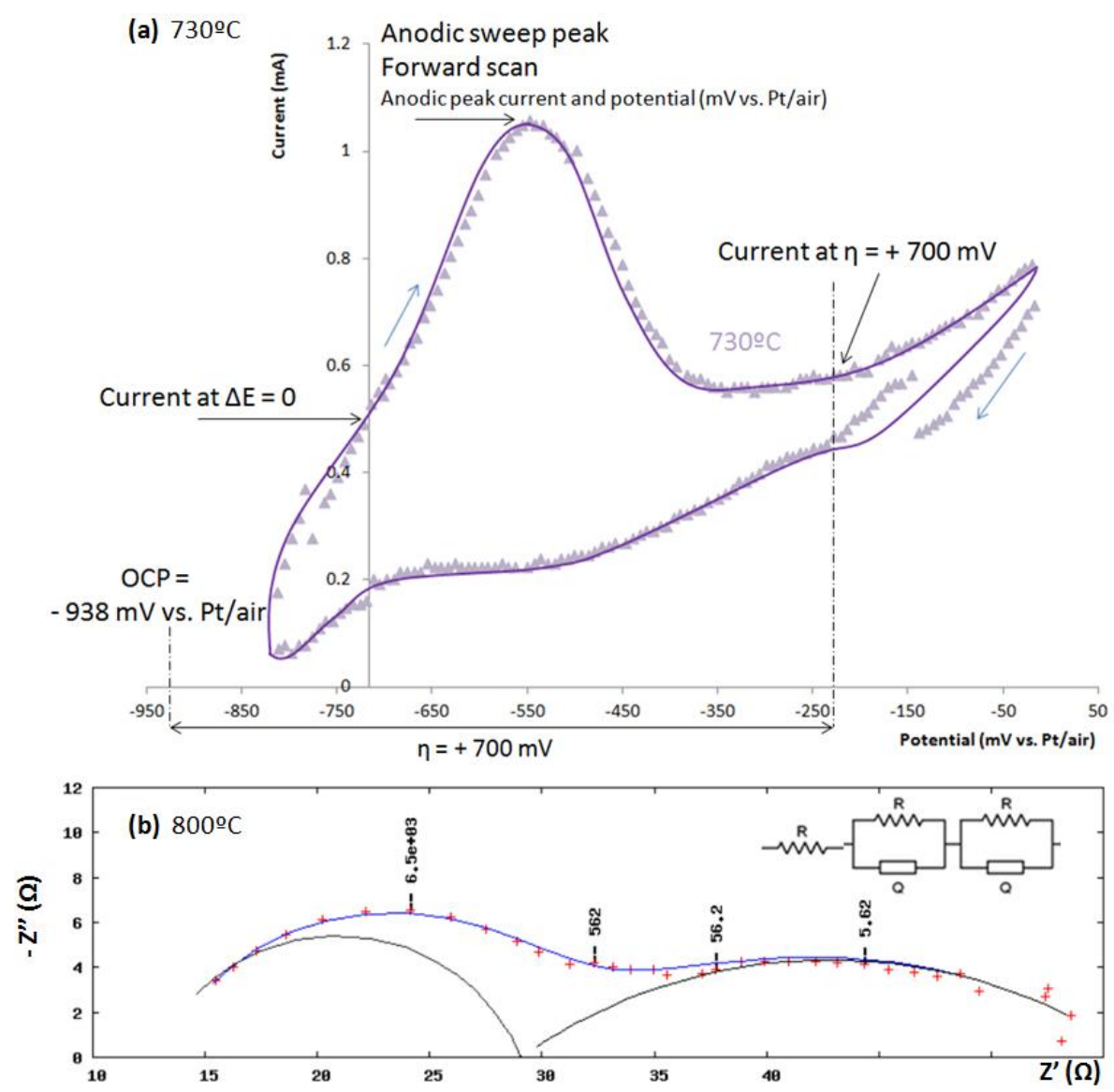

Fig. 2 - With Ni-YSZ WE. (a) Cyclic voltammetry data acquired at $730{ }^{\circ} \mathrm{C}(+700 \leftrightarrow-100 \mathrm{mV}$ vs. $\mathrm{Pt} / \mathrm{CO}-\mathrm{CO}_{2}$ ) and (b) EIS data acquired at $800{ }^{\circ} \mathrm{C}$, for carbon black in $96-4 \mathrm{~N}_{2}-\mathrm{CO}_{2}$ in contact with a Ni-YSZ WE. Points represent data acquired. In (b), line and arcs are generated from model circuit (inset) fitting. Frequency values are given in $\mathrm{Hz}$. 

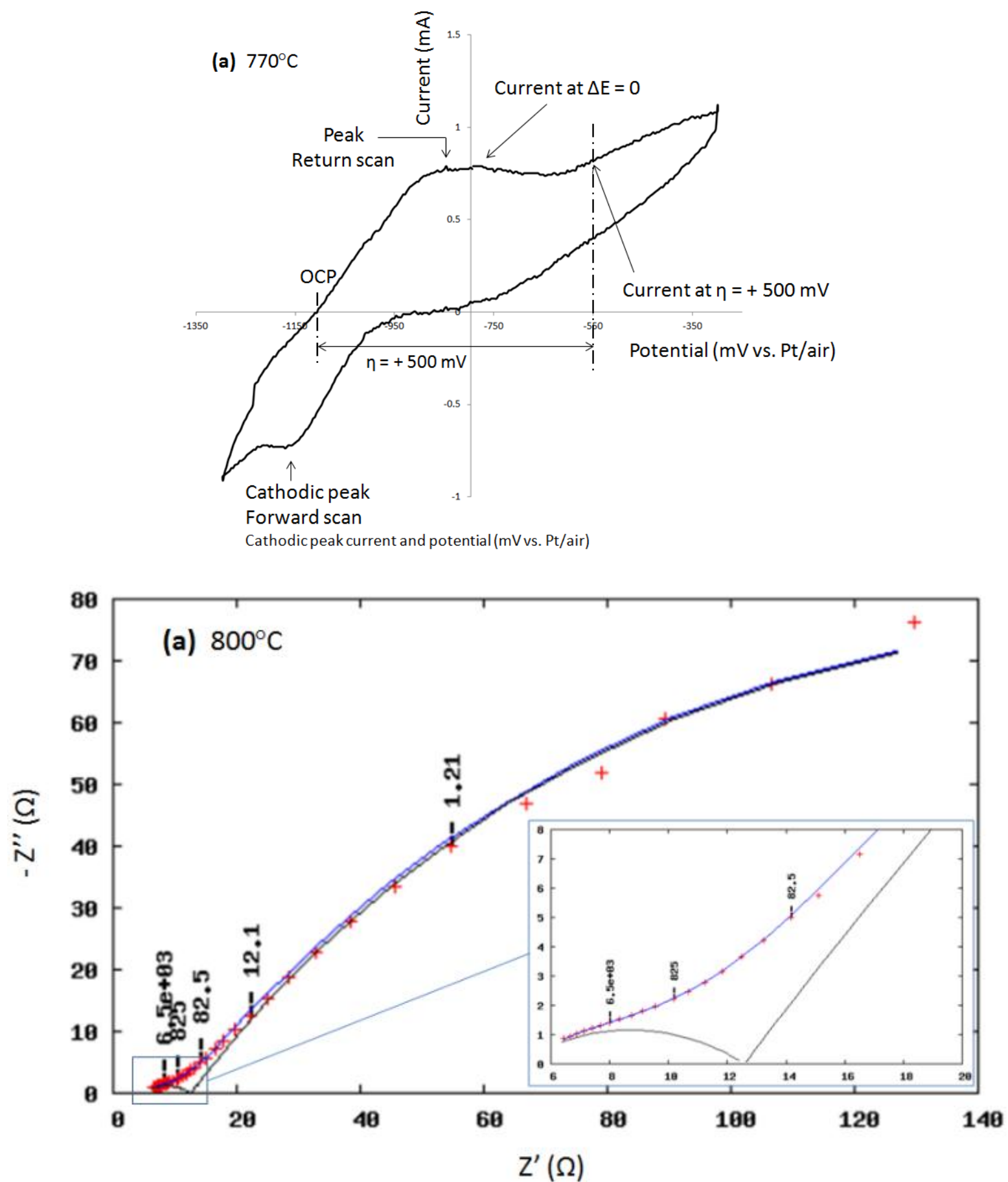

Fig. 3 - Without Ni-YSZ WE. (a) CV data acquired at $770{ }^{\circ} \mathrm{C}\left( \pm 500 \mathrm{mV}\right.$ vs. $\left.\mathrm{Pt} / \mathrm{CO}-\mathrm{CO}_{2}\right)$ and (b) EIS data acquired at $800{ }^{\circ} \mathrm{C}$, for carbon black in $96-4 \mathrm{~N}_{2}-\mathrm{CO}_{2}$ in contact the YSZ electrolyte (no NiYSZ anode layer). Points represent data acquired, line and arcs are generated from model circuit fitting. 
As illustrated in Figs. 2 and 3, currents at $\Delta \mathrm{E}=0$ and at fixed overpotential $(\eta=+500-700 \mathrm{mV})$, as well as peak currents (Fig. 2(a)), were measured. These are plotted as a function of temperature in Fig. 4. Currents tended to increase as temperature increased, as seen previously for catalyzed $\left(\mathrm{Ag}_{2} \mathrm{O}\right)$ carbon black systems (with Ni-YSZ WE layer) [4]. Performance tended to be higher, seen as greater current at fixed overpotential (Fig. 4) and lower Rp values at $800{ }^{\circ} \mathrm{C}$ (Figs. 2-3(b)) in the presence of the Ni-YSZ anode layer. Similarly, Dudek et al. (2014) found inclusion of a Ni-YSZ layer improved the performance of a SOFC-type DCFC full-cell fueled with graphite and carbon black (Ar sweep gas, $600-800^{\circ} \mathrm{C}$ ) [24].

Nyquist plots acquired at $800{ }^{\circ} \mathrm{C}$ with (Fig. 2(b)) and without (Fig. 3(b)) the Ni-YSZ layer both evidenced large Rs values due to the electrolyte-supported half-cell configuration. These consisted of 2 arcs, with the HF contribution, likely arising from the charge transfer reaction(s), being smaller [7]. The LF arc, consisting of mass transfer processes in the WE chamber, was significantly larger in the absence of the Ni-YSZ layer. This may arise from a lower number of electrochemically active sites in the absence of a porous (high surface area) anode/WE layer [25]. 

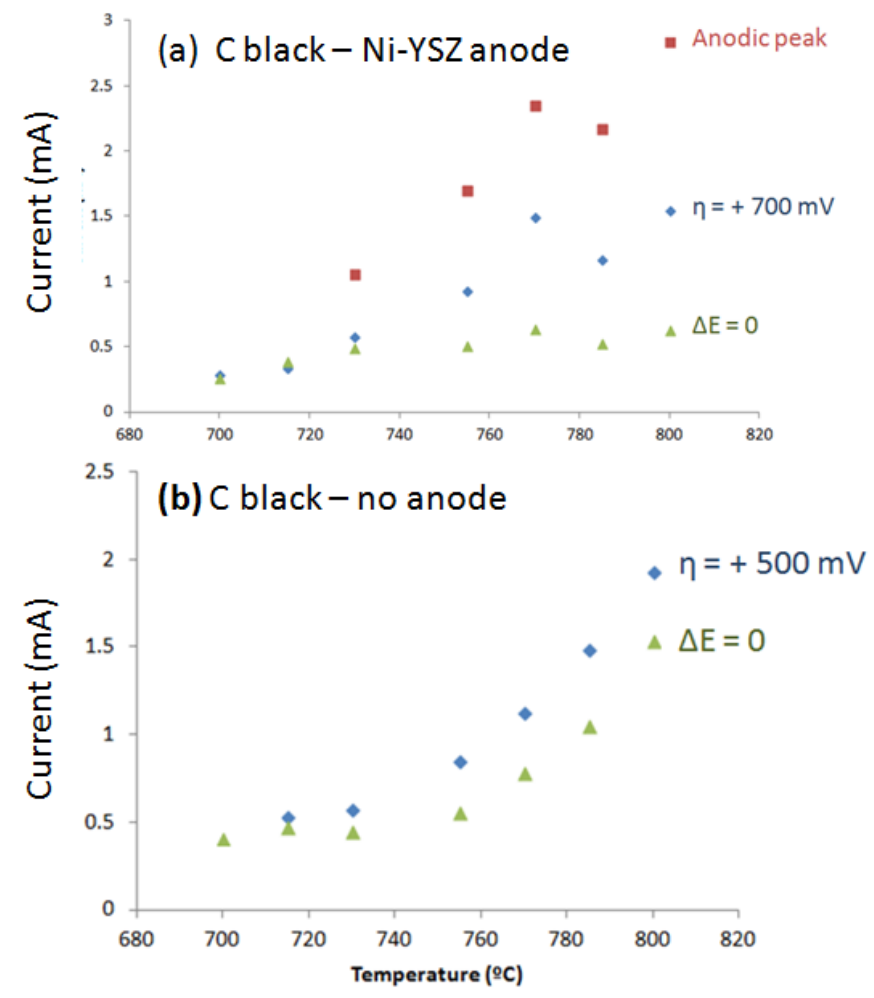

Fig. 4 - Carbon black. Current, determined from $C V$, when potential difference was zero $(\Delta \mathrm{E}=0$ vs. $\left.\mathrm{Pt} / \mathrm{CO}-\mathrm{CO}_{2}\right)$ and at fixed overpotential $(\eta=500-700 \mathrm{mV})$ as a function of temperature, for carbon black in 96-4 $\mathrm{N}_{2}-\mathrm{CO}_{2}$ both (a) with and (b) without a Ni-YSZ WE.

Fig. 5 illustrates OCP values as a function of temperature measured for carbon black (C black) both with and without the Ni-YSZ WE layer. Values were found to increase with temperature [6] and did not depend on the presence of the catalyst layer. As inclusion of the WE layer proved advantageous (Fig. 4), it was included in all subsequent half-cell experiments. 


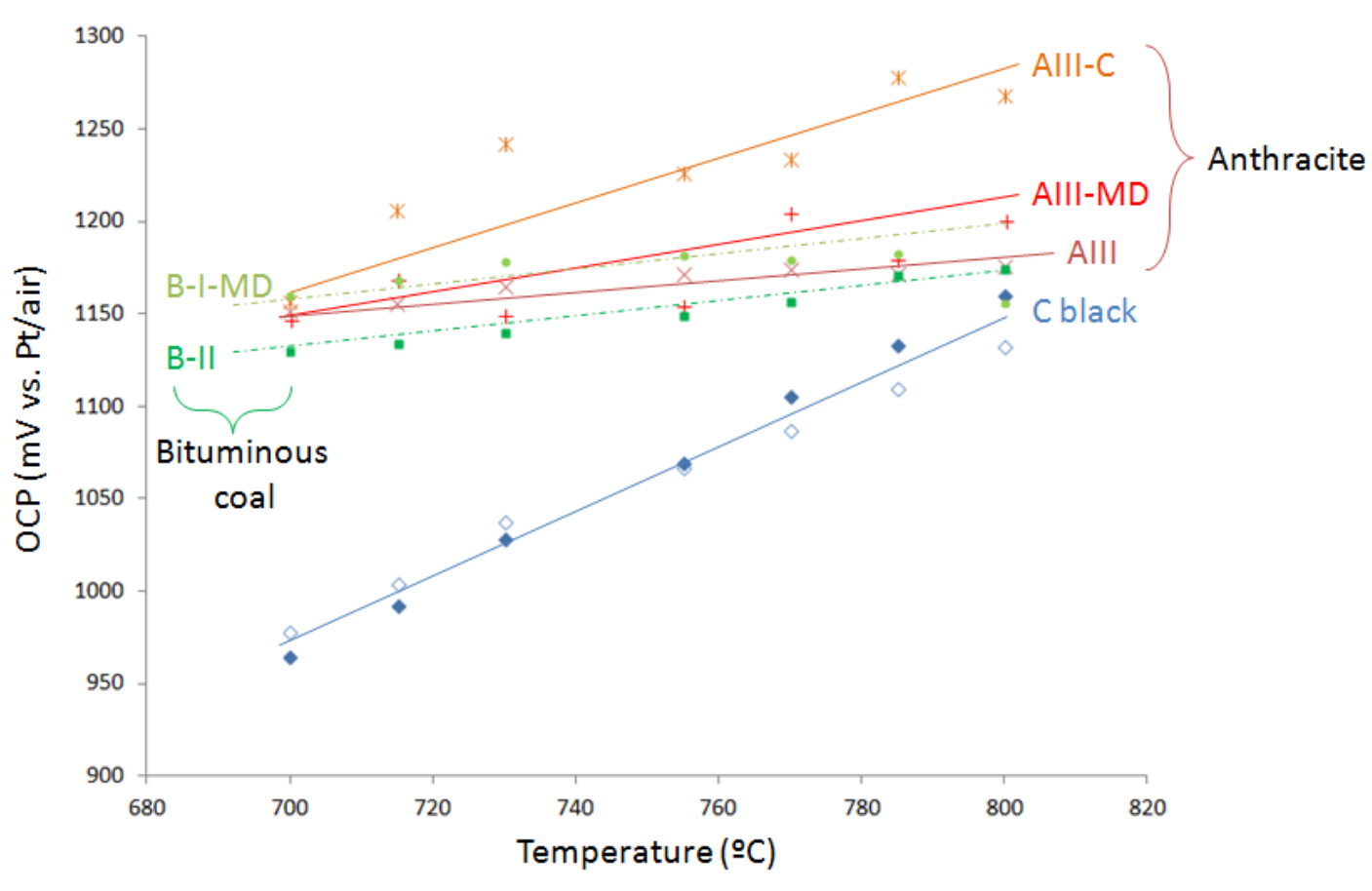

Fig. 5 - OCP. OCP values given as a function of temperature in $96-4 \mathrm{~N}_{2}-\mathrm{CO}_{2}$ for carbon black $(\diamond)$, with (closed symbol) and without (open symbol) a Ni-YSZ WE, bituminous (B-I-MD (०) and B-II (ロ)) and anthracite coals (AIII (×), AIII-MD (+) and AIII-C (*)).

\subsection{Carbon fuel}

Similar to carbon black-fueled systems, performance was measured in $96-4 \mathrm{~N}_{2}-\mathrm{CO}_{2}$ as a function of temperature in the presence of bituminous (B-I and B-II) and anthracite (AIII) coals. At $800{ }^{\circ} \mathrm{C}$, carbon black and treated coals gave OCP values of $1200 \pm 50 \mathrm{mV}$ vs. Pt/air. As illustrated in Fig. 5, OCP values tended to increase as a function of temperature regardless of carbon fuel, but coals gave higher OCP values than carbon black, especially at lower temperatures $\left(700^{\circ} \mathrm{C}\right)$.

From CVs acquired in the presence of various fuels, currents were measured at fixed overpotential $(\eta=500 \mathrm{mV})$ as a function of temperature $[6,8,17,18]$. In Fig. 6, these are plotted according to the Arrhenius relationship, allowing determination of activation energies (Ea). For each carbon fuel, Ea values, as well as OCP and currents measured at $800{ }^{\circ} \mathrm{C}$, are given in Table 2. Activation energies were found to be $1.2 \pm 0.3 \mathrm{eV}$, regardless of carbon fuel and the presence/absence of the Ni-YSZ 
WE layer (carbon black). Reported chemical activation energies $\left(\mathrm{G}_{\mathrm{A}}\right)$, a value calculated from open circuit voltage (OCV) values acquired in a MCFC-type DCFC half-cell setup for carbon black (N220 and N660) loaded at $5 \mathrm{wt} \%$ in $(\mathrm{Li}, \mathrm{Na}, \mathrm{K})_{2} \mathrm{CO}_{3}$, between 600 and $800^{\circ} \mathrm{C}$ under $\mathrm{Ar}$, were similar (101-105 kJ/mol, 1.05-1.09 eV) [8]. Additionally, similarity between coal (sub-bituminous) and carbon black activation energies $\left(750-925^{\circ} \mathrm{C}\right)$ has previously been reported for SOFC-type DCFCs ((Ar) Ni-YSZ|YSZ|LSM $\left.\left(\mathrm{O}_{2}\right)\right)$ [26].

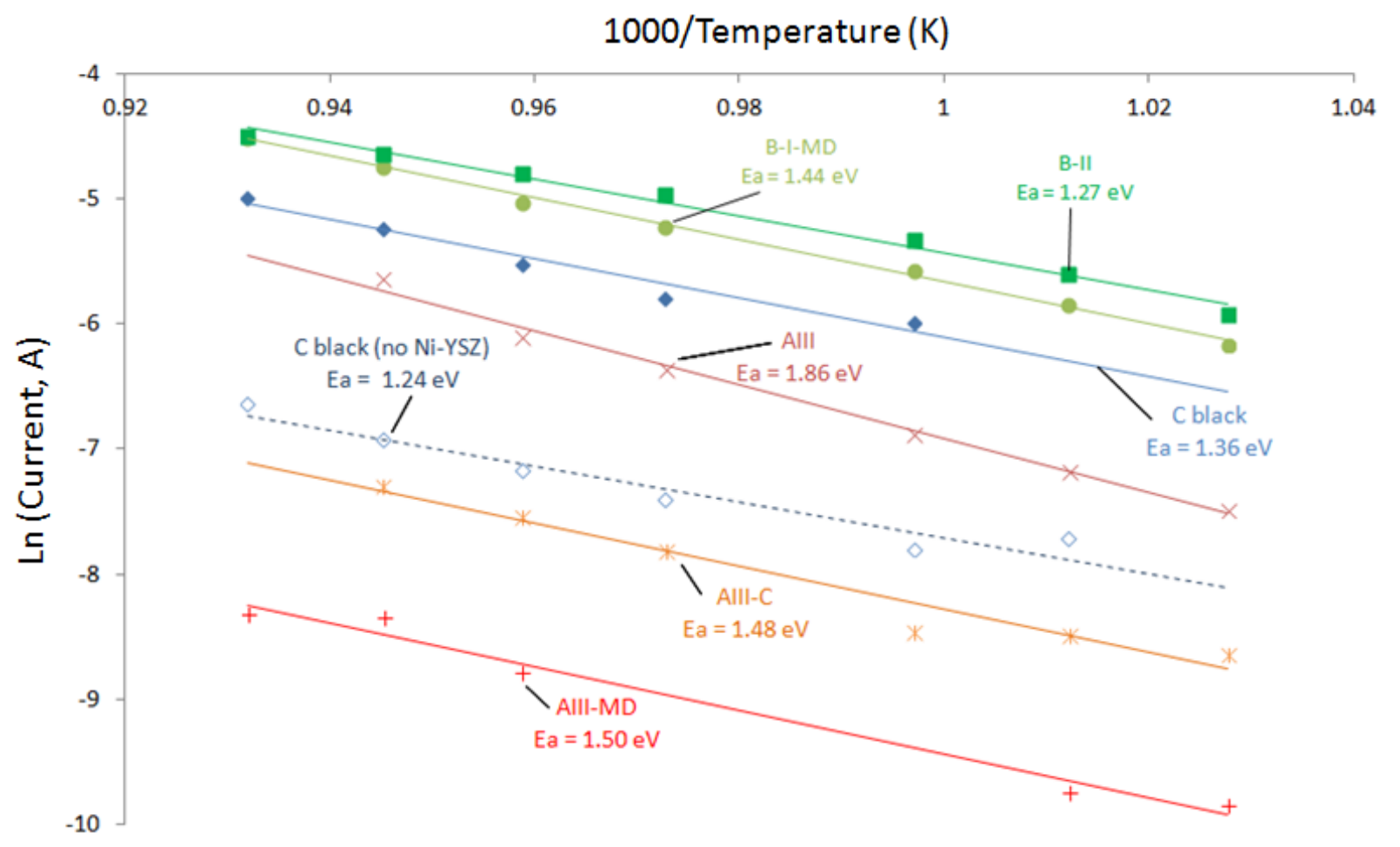

Fig. 6 - Activation energies. Arrhenius plot of the natural logarithm of current, determined from $\mathrm{CV}$ at fixed overpotential $(\eta=500 \mathrm{mV})$, as a function of inverse temperature in $96-4 \mathrm{~N}_{2}-\mathrm{CO}_{2}$, for carbon black $(\diamond)$, with (closed symbol) and without (open symbol) a Ni-YSZ WE, as well as bituminous (B-I-MD (०) and B-II ( $\square)$ ) and anthracite coals (AIII (×), AIII-MD (+) and AIII-C (*)). Activation energies are given in $\mathrm{eV}$. 
The electrochemical performance, primarily measured as the maximum power density, of various fuels [8, 14], including treated coals [10], has been linked with diverse fuel characteristics, including surface area, particle size, pore size distribution, crystallinity, and properties determined by proximate and ultimate analysis. The proximate and ultimate analysis for carbon black [27] and treated coals are shown in Table 2. These coals were further tested in a full-cell electrochemical setup and the relationship between fuel properties and electrochemical activity is discussed in more detail in another report [28].

Overall, evaluated at $800^{\circ} \mathrm{C}$, bituminous coals showed higher activity under load, as larger currents were measured at fixed overpotential. Over the range of fuels tested, OCP and measured current did not show any strong trending relationship with fuel physical and chemical properties. However, fuels which gave rise to high currents at fixed overpotential (e.g., B-I-MD, $11.1 \mathrm{~mA}$ ) tended to have smaller OCPs (e.g., B-I-MD, $1156 \mathrm{mV}$ ). Fuels with lower wt\% C and fixed carbon (FC) content tended to display lower magnitude OCP values. Activation energies tended to decrease (processes became more facile) as wt $\% \mathrm{H}$ and volatile matter content increased. Enhanced reactivity of coals with higher wt\% $\mathrm{H} \mathrm{[11]} \mathrm{and} \mathrm{the} \mathrm{significance} \mathrm{of} \mathrm{volatile} \mathrm{matter} \mathrm{[29]} \mathrm{have} \mathrm{previously} \mathrm{been} \mathrm{reported}$ for MCFC-type DCFCs $\left((\mathrm{Li}-\mathrm{K})_{2} \mathrm{CO}_{3}, 700{ }^{\circ} \mathrm{C}\right)$. 
Table 2 - Ultimate and proximate analysis, OCP and current at fixed overpotential $(\eta=500 \mathrm{mV})$ determined from $\mathrm{CVs}$ acquired at $800{ }^{\circ} \mathrm{C}$ and activation energy determined in $96-4$ vol\% $\mathrm{N}_{2}-\mathrm{CO}_{2}$ for various carbon sources.

\begin{tabular}{|c|c|c|c|c|c|c|c|c|c|c|c|c|}
\hline \multirow[t]{2}{*}{ Carbon } & \multicolumn{4}{|c|}{$\begin{array}{c}\text { Proximate analysis } \\
(w t \%)\end{array}$} & \multicolumn{5}{|c|}{$\begin{array}{l}\text { Ultimate analysis } \\
\text { (wt\% daf d basis) }\end{array}$} & \multirow[t]{2}{*}{$\begin{array}{r}O C P^{e} \\
(m V)\end{array}$} & \multirow[t]{2}{*}{$\begin{array}{c}I^{f} \\
(\boldsymbol{m A})\end{array}$} & \multirow[t]{2}{*}{$\begin{array}{c}E a \\
(e V)\end{array}$} \\
\hline & $\mathrm{FC}^{\mathrm{a}}$ & $\mathrm{VM}^{\mathrm{b}}$ & Ash & $\mathrm{MC}^{\mathrm{c}}$ & $\bar{C}$ & $\mathrm{H}$ & $\mathrm{N}$ & $S$ & $\mathrm{O}$ & & & \\
\hline C black ${ }^{\mathrm{g}}$ & 99.6 & 0.4 & - & - & 99.8 & 0.1 & - & - & 0.1 & 1161 & 6.9 & 1.36 \\
\hline B-I-MD & 80.5 & 17.9 & 0.4 & 1.2 & 89.9 & 4.3 & 1.6 & 0.7 & 3.5 & 1156 & 11.1 & 1.44 \\
\hline B-II & 73.4 & 19.3 & 6.7 & 0.7 & 90.4 & 4.6 & 1.5 & 0.7 & 2.8 & 1175 & 11.2 & 1.27 \\
\hline AIII & 83.8 & 4.0 & 9.9 & 2.3 & 93.1 & 2.0 & 0.9 & 1.0 & 3.0 & 1176 & 9.3 & 1.86 \\
\hline AIII-MD & 93.3 & 5.0 & 1.2 & 0.6 & 93.1 & 2.3 & 1.0 & 1.1 & 2.5 & 1201 & 0.3 & 1.50 \\
\hline AIII-C & 96.0 & 1.0 & 1.9 & 1.1 & 95.6 & 1.2 & 1.1 & 1.1 & 1.0 & 1268 & 1.3 & 1.48 \\
\hline \multicolumn{13}{|c|}{${ }^{\mathrm{a}}$ fixed carbon } \\
\hline \multicolumn{13}{|c|}{$\mathrm{b}$ volatile matter } \\
\hline \multicolumn{13}{|c|}{${ }^{\mathrm{c}}$ moisture content } \\
\hline \multicolumn{13}{|c|}{${ }^{\mathrm{d}}$ dry, ash-free basis (daf) } \\
\hline \multicolumn{13}{|c|}{${ }^{\mathrm{e}} \mathrm{OCP}$ (mV vs. Pt /air) } \\
\hline${ }^{\mathrm{f}}$ current ( & A) $m$ & surec & t fix & ove & oten & 1 & $=50$ & $0 \mathrm{mV}$ & & & & \\
\hline
\end{tabular}

\subsection{Atmosphere composition}

\subsection{1 $\mathrm{N}_{2}-\mathrm{CO}_{2}$ VS. CO-CO 2}

Fresh half-cells were tested in mixed $\mathrm{N}_{2}-\mathrm{CO}_{2}$ environments at fixed temperature (e.g., $700{ }^{\circ} \mathrm{C}$, Fig. 7(a) and $800^{\circ} \mathrm{C}$, Fig. 7(b)). As a function of operating time, carbon fuel initially in contact with the anode layer, and current collector, was expected to be consumed [26, 30], leaving a more depleted region immediately adjacent to the Ni-YSZ layer. Aged cells (operating time $>48-72$ hrs) were tested in 50-50 $\mathrm{CO}-\mathrm{CO}_{2}$ as a function of temperature. Due to the depletion of the carbon bed in the 
proximity of the WE layer and the gaseous nature of the introduced $\mathrm{CO}$, this fuel was expected to be consumed first. This is in contrast to $\mathrm{CO}$ fuel generated within the carbon-carbonate bed, which must first be formed chemically through the gasification of carbon (e.g., $\mathrm{CO}_{2}$ promoted Boudouard gasification).

Fig. 7(a) illustrates typical $\mathrm{CV}$ curves acquired in $96-4 \mathrm{~N}_{2}-\mathrm{CO}_{2}$ and $50-50 \mathrm{CO}-\mathrm{CO}_{2}$ at $700{ }^{\circ} \mathrm{C}$ in the presence of treated anthracite (AIII-MD), although similar features were observed over the temperature range $\left(700-800{ }^{\circ} \mathrm{C}\right)$ and fuels investigated. Additionally, a representative Nyquist plot acquired in 96-4 $\mathrm{N}_{2}-\mathrm{CO}_{2}$ at $800{ }^{\circ} \mathrm{C}$ is shown in Fig. 7(b). In contrast to Figs. 2 and 3, no peaks were observed in these CV curves. This is not a unique feature of the coal fuel, as the appearance/absence of peaks depended on the individual loading conditions of each half-cell experiment. Such that peaks, similar to those observed in Fig. 2(a), were observed in the presence of anthracite coal, and were absent in several carbon black acetylene fueled tests. Several LSV curves relatively similar to the anodic sweep of CVs shown in Fig. 7(a) have been reported $\left(15 \mathrm{wt} \%\right.$ coal (in $\left.\mathrm{CO}_{3}\right), 700{ }^{\circ} \mathrm{C} /$ $\mathrm{CO}_{2}$, [6]; 5 wt $\%$ graphite, $600{ }^{\circ} \mathrm{C} / \mathrm{Ar}$ [8]; monolithic graphite, $650{ }^{\circ} \mathrm{C} / \mathrm{CO}_{2}$ [12]; 5 wt $\%$ biochar, unstirred, $700{ }^{\circ} \mathrm{C} / \mathrm{He}[14]$; monolithic coal, $\left.500{ }^{\circ} \mathrm{C} / \mathrm{CO}_{2}[22]\right)$. 


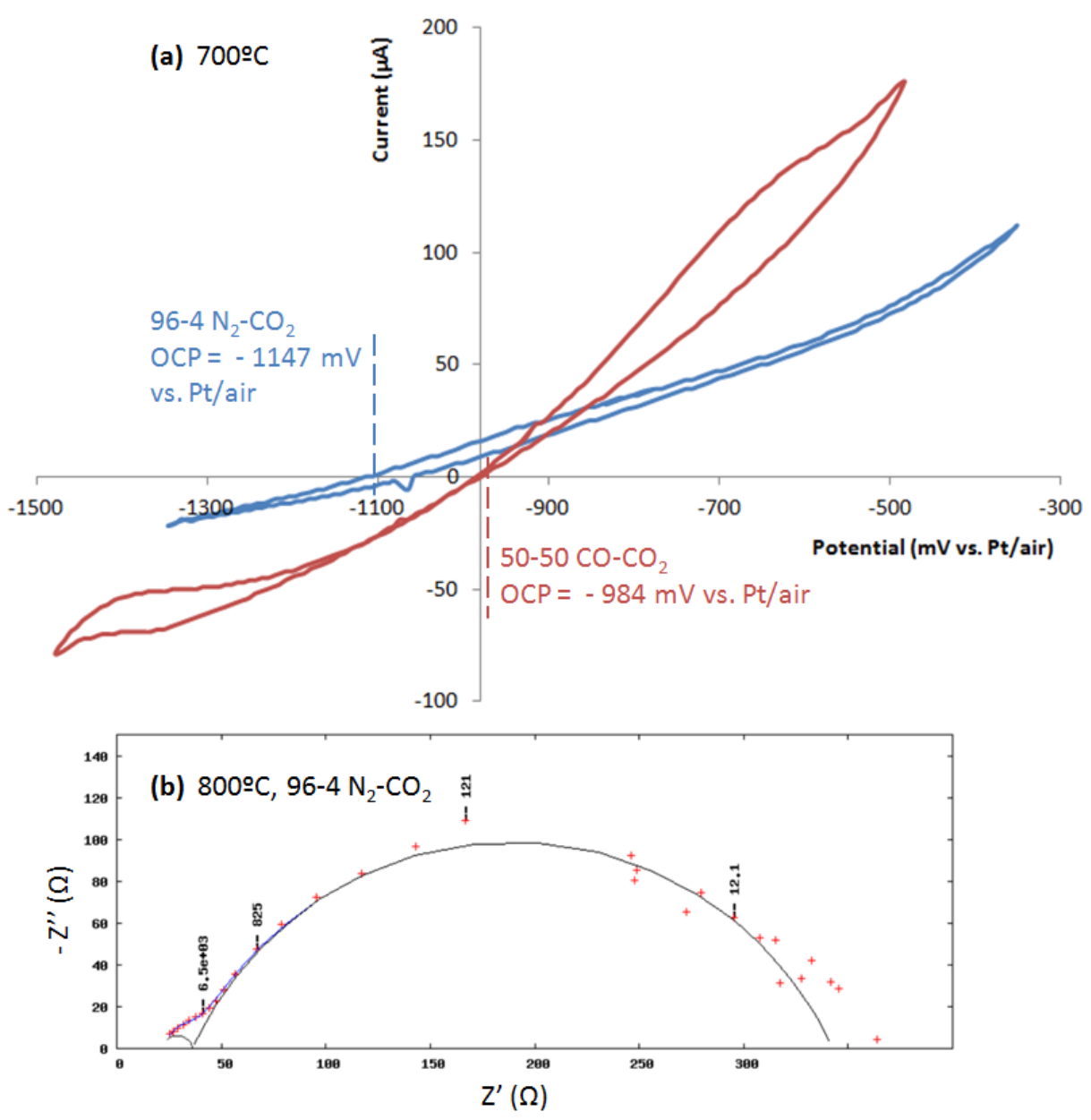

Fig. 7 - Anthracite coal. For an anthracite coal (AIII-MD), (a) CV data acquired at $700{ }^{\circ} \mathrm{C}( \pm$ $500 \mathrm{mV}$ vs. $\mathrm{Pt} / \mathrm{CO}-\mathrm{CO}_{2}$ ) in $96-4 \mathrm{~N}_{2}-\mathrm{CO}_{2}$ and $50-50 \mathrm{CO}-\mathrm{CO}_{2}$, and (b) EIS data acquired at $800{ }^{\circ} \mathrm{C}$ in 96-4 $\mathrm{N}_{2}-\mathrm{CO}_{2}$. Points represent data acquired, line and arcs are generated from model circuit fitting; frequency values are given in $\mathrm{Hz}$.

The magnitude of the OCP tended to be larger in $96-4 \mathrm{~N}_{2}-\mathrm{CO}_{2}$, although this may be related to the aging of the cell as a function of operation time. Fresh cells showed higher OCP values, which declined slowly over the testing period (120 hrs) when conditions were held constant. Interestingly, in 50-50 CO- $-\mathrm{CO}_{2}$, the OCP $(\mathrm{I}=0)$ coincided with the point of no potential difference $(\Delta \mathrm{E}=0)$. This is in contrast to mixed $\mathrm{N}_{2}-\mathrm{CO}_{2}$ environments, where current was observed at $\Delta \mathrm{E}=0$ (Fig. 4), as reported previously for carbon black [4]. The coincidence of OCP and $\Delta \mathrm{E}=0$ when $\mathrm{CO}$ was 
introduced to the half-cell apparatus may reflect the similarity in gas environment at the WE and RE, and suggested that one equilibrium was setting the potential at both electrodes, the $\mathrm{CO} / \mathrm{CO}_{2}$ redox couple $\left(\mathrm{Ni}-\mathrm{YSZ} / \mathrm{CO}-\mathrm{CO}_{2}\right.$ vs. $\left.\mathrm{Pt} / \mathrm{CO}-\mathrm{CO}_{2}\right)$. As $\mathrm{OCP}$ and $\Delta \mathrm{E}=0$ did not coincide in mixed $\mathrm{N}_{2-}$ $\mathrm{CO}_{2}$, there exists the possibility that additional reactions were occurring at the WE, such that these were not in equilibrium with the reduction of $\mathrm{CO}_{2}$ occurring at the $\mathrm{RE}$ [4].

Fig. 8(a) shows OCP values acquired in $96-4 \mathrm{~N}_{2}-\mathrm{CO}_{2}$ and $50-50 \mathrm{CO}-\mathrm{CO}_{2}$ for an anthracite coal (AIII-MD) as a function of temperature $\left(700-800{ }^{\circ} \mathrm{C}\right)$. In a binary $\mathrm{CO}-\mathrm{CO}_{2}$ fueled SOFC, under non-coking conditions (higher $\mathrm{CO}_{2}$ content, lower temperature) [31], the OCV decreases as temperature is increased [32]. However, in the presence of solid carbon and at temperatures which favor the Boudouard equilibrium $\left(\mathrm{T}>700{ }^{\circ} \mathrm{C}\right)$, the electrochemical potential was predicted to increase as temperature increased [31]. This was consistent with OCP values recorded in 50-50 CO$\mathrm{CO}_{2}$ in the presence of anthracite (Fig. 8(a)) and carbon black [5]. 

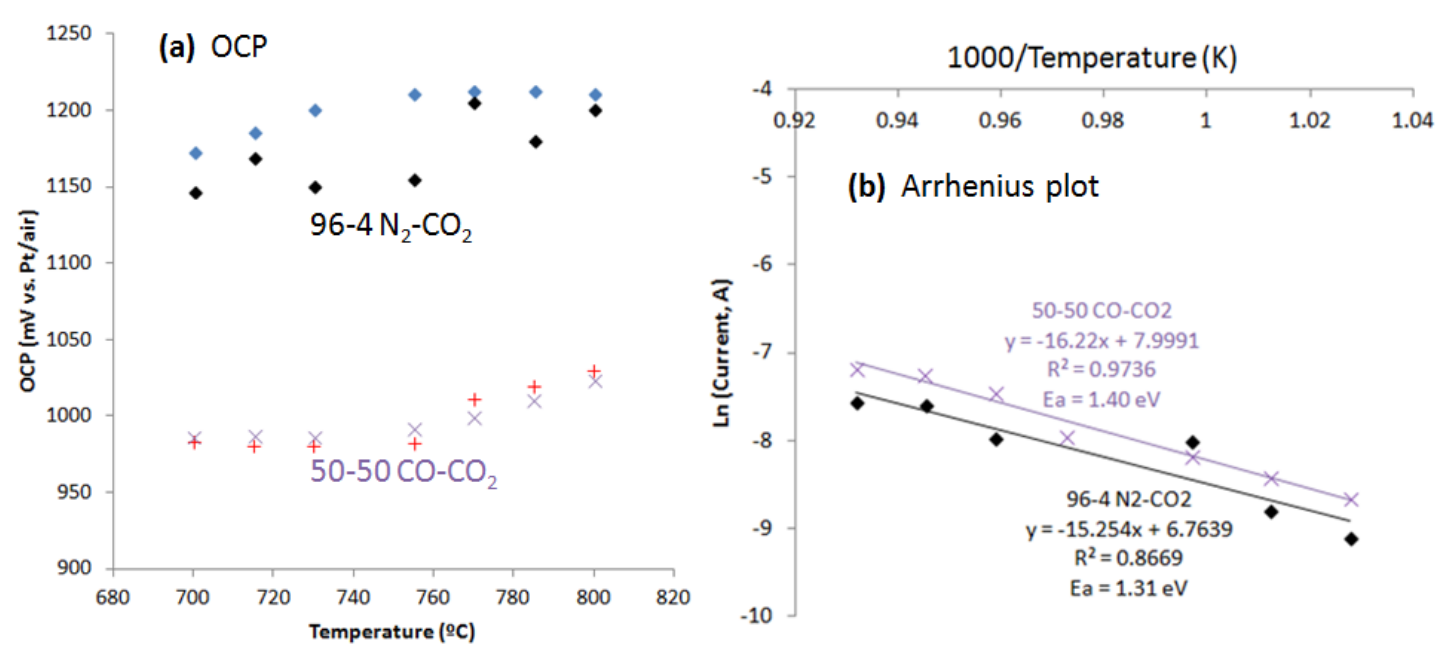

Fig. 8 - Working atmosphere. For an anthracite coal (AIII-MD), (a) OCP (2 replicates shown) as a function of temperature, and (b) Arrhenius plot of the natural logarithm of current, determined from $\mathrm{CV}$ at fixed overpotential $(\eta=500 \mathrm{mV})$, as a function of inverse temperature, in $96-4 \mathrm{~N}_{2}-\mathrm{CO}_{2}$ $(\diamond)$ and $50-50 \mathrm{CO}-\mathrm{CO}_{2}(+, \mathrm{x})$

Fig. 7(a) shows that electrochemical performance recorded in the presence of supplied CO was generally higher (larger current values) relative to mixed $\mathrm{N}_{2}-\mathrm{CO}_{2}$. For $96-4 \mathrm{~N}_{2}-\mathrm{CO}_{2}$ and 50-50 CO$\mathrm{CO}_{2}$, current was measured at fixed overpotential $(\eta=500 \mathrm{mV})$ as a function of temperature, and plotted according to the Arrhenius relationship in Fig. 8(b). In $96-4 \mathrm{~N}_{2}-\mathrm{CO}_{2}$, measured activation energies for treated anthracite (AIII-MD) were $1.31 \mathrm{eV}$ (Fig. 8(b)) and $1.50 \mathrm{eV}$ (Fig. 6), which are within the range determined for the various fuels tested $(1.2 \pm 0.3 \mathrm{eV}$, Fig. 6). A similar value was determined in 50-50 CO- $\mathrm{CO}_{2}(1.40 \mathrm{eV})$. This suggested that with (50-50 $\left.\mathrm{CO}-\mathrm{CO}_{2}\right)$ and without (96$4 \mathrm{~N}_{2}-\mathrm{CO}_{2}$ ) the addition of $\mathrm{CO}$, and regardless of fuel type, there was one rate determining step (RDS) giving rise to these activation energies. These Ea values are similar to those reported for CO oxidation, in the absence of carbon, on a Ni-YSZ anode $(0.85-1.42 \mathrm{eV})$ [33]. The RDS may be similar/related to the transfer of adsorbed oxygen to an adsorbed $\mathrm{CO}$ moiety on the Ni surface of a Ni-YSZ anode, as this process is reported to have a comparable Ea (123.6 kJ/mol, $1.28 \mathrm{eV})$ [34]. 
For molten carbon-carbonate slurries, a related process $\left(\mathrm{CO}_{\text {ads }}+\mathrm{O}^{2-} \rightarrow \mathrm{CO}_{2}{ }^{2-}\right.$ ads $)$ has been suggested as the RDS for a carbon black-fueled MCFC-type DCFC (1.05-1.09 eV) [8].

\subsubsection{MIXED $\mathrm{N}_{2}-\mathrm{CO}_{2}$}

We have previously reported on the effects of variable $\% \mathrm{CO}_{2}$ in mixed $\mathrm{N}_{2}-\mathrm{CO}_{2}$ environments on carbon black fueled HDCFC performance, both in full-cell [2] and half-cell [4] configurations. Previously reported half-cell tests showed that current measured at fixed overpotential increased, and $\mathrm{Rp}$ values decreased, as the $\% \mathrm{CO}_{2}$ was increased. These results were observed for carbon black, as illustrated at $700{ }^{\circ} \mathrm{C}$ in Fig. 9(a), and various treated coals [5], and in the presence of a catalyst $\left(\mathrm{Ag}_{2} \mathrm{O}[4]\right)$, over the range of temperatures tested $\left(700-800{ }^{\circ} \mathrm{C}\right)$.

However, these trends were only observed in a number of half-cell tests. Identical experimental replicates, regardless of temperature, carbon fuel or catalyst, occasionally showed different dependence of cell activity towards varied $\mathrm{CO}_{2}$ concentrations. As illustrated for two identical carbon black-fueled replicates at $700{ }^{\circ} \mathrm{C}$ (Fig. 9(a)) and $770{ }^{\circ} \mathrm{C}$ (Fig. 9(b)), the magnitude of OCP values tended to decrease as $\% \mathrm{CO}_{2}$ increased, as expected [35] for a working atmosphere containing $\mathrm{CO}_{2}$ (introduced) and $\mathrm{CO}$ (formed in situ) reactive (chemically and electrochemically, respectively) gases. In contrast, Fig. 9(b) illustrates decreased activity, as decreasing current at fixed overpotential and increasing $\mathrm{Rp}$, as $\% \mathrm{CO}_{2}$ was increased. Although Fig. 9 includes two temperature conditions, it should be noted that these contrasting trends in cell activity with $\mathrm{CO}_{2}$ content were observed regardless of temperature and fuel. These differing dependencies on experimental conditions are suggested to arise from differences in loading conditions of replicate experiments, such as quality of contact with the current collector, initial packing density of the carbon-carbonate bed, etc. 

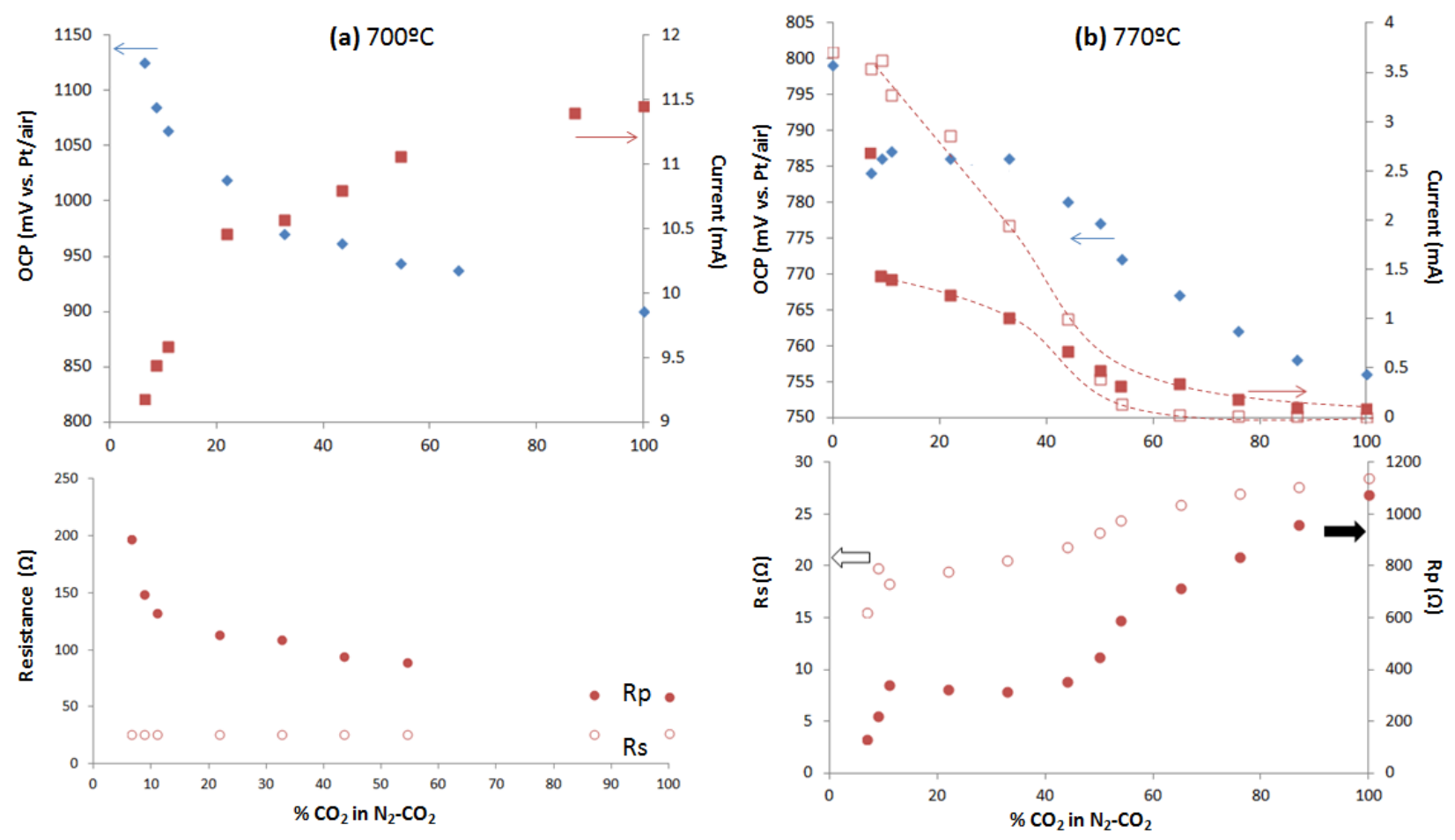

Fig. 9 - \% $\mathrm{CO}_{2}$ in $\mathbf{N}_{2}-\mathbf{C O}_{2}$. For carbon black at (a) $700{ }^{\circ} \mathrm{C}$ and (a) $770{ }^{\circ} \mathrm{C}$, OCP $(\diamond)$ and current ( $\square$ ), determined from $\mathrm{CV}$ at fixed overpotential $(\eta=500 \mathrm{mV})$, and resistance $(\circ)$ values determined from EIS (Rs (open symbol) and Rp (closed symbol)), acquired as a function of vol\% $\mathrm{CO}_{2}$ in $\mathrm{N}_{2}$ $\mathrm{CO}_{2}$.

\section{Discussion}

\subsection{Reaction mechanism}

We have discussed reactions potentially occurring in the vicinity of the WE in more detail elsewhere [1]. Briefly, there appear to be two prevailing theories on the dominant electrochemical reaction occurring in molten carbon-carbonate slurry DCFCs (co-electrolyte, MCFC-type DCFCs and HDCFCs): the complete oxidation of carbon (4 electron process) [36] and CO oxidation (2 electron process) [31]. We have previously suggested that the $\mathrm{CO}$ oxidation process likely predominates at the anode of planar HDCFCs [2]. Although non-coincident $\mathrm{OCP}$ and $\triangle \mathrm{E}=0$ values seen in our half-cell experiments in mixed $\mathrm{N}_{2}-\mathrm{CO}_{2}$ (Fig. 7, [4]) may suggest that other reactions 
contribute, we suggest $\mathrm{CO}$ oxidation is the dominant electrochemical reaction at the WE as well. A basic sequence of steps occurring near the WE when $\mathrm{CO}_{2}$ is introduced into the half-cell apparatus is given in Steps A-J. The final step in this sequence is the release of adsorbed $\mathrm{CO}_{2}$ from the electrochemically active surface, called the triple phase boundary (TPB), which may proceed through Step I or Step J.
A. $\mathrm{CO}_{2(\mathrm{~g})}+\mathrm{CO}_{3}$, liquid $\leftrightarrow \mathrm{CO}_{2, \mathrm{CO} 3}$
Dissolution in molten carbonate
B. $\mathrm{CO}_{2, \mathrm{CO} 3}$
Transport as dissolved species, to $\mathrm{C}_{(\mathrm{s})}$ surface
C. $\mathrm{CO}_{2, \mathrm{CO} 3} \leftrightarrow \mathrm{CO}_{2}$, ads
$\mathrm{CO}_{2}$ adsorption
D. $\mathrm{C}_{(\mathrm{s})}+\mathrm{CO}_{2}$, ads $\leftrightarrow 2 \mathrm{CO}_{\text {ads }}$
Boudouard Reaction
E. $\mathrm{CO}_{\text {ads }} \leftrightarrow \mathrm{CO}_{\mathrm{CO} 3}$
CO desorption
F. $\mathrm{CO}_{\mathrm{CO} 3}$
Transport as dissolved species, to TPB
G. $\mathrm{CO}_{\mathrm{CO} 3} \leftrightarrow \mathrm{CO}_{\mathrm{ads}}(\mathrm{TPB})$
CO adsorption
H. $\mathrm{CO}_{\text {ads }}(\mathrm{TPB})+\mathrm{O}^{2-} \rightarrow \mathrm{CO}_{2, \text { ads }}(\mathrm{TPB})+2 \mathrm{e}^{-}$
CO electrochemical oxidation
I. $\mathrm{CO}_{2, \text { ads }}(\mathrm{TPB}) \leftrightarrow \mathrm{CO}_{2}, \mathrm{CO} 3$
$\mathrm{CO}_{2}$ desorption
J. $\quad \mathrm{CO}_{2, \text { ads }}(\mathrm{TPB}) \leftrightarrow \mathrm{CO}_{2}$ (g) $($ bubble $)$
$\mathrm{CO}_{2}$ desorption and bubble formation

When cell activity was promoted by the addition of $\mathrm{CO}_{2}$, the situation in Fig. 9(a), the processes occuring at the WE are proposed to proceed through Steps A-H + Step I. As illustrated in Fig. 10, the final step (Step I) involves the desorption of $\mathrm{CO}_{2}$ into an under-saturated molten medium, i.e., the concentration of dissolved $\mathrm{CO}_{2}$ remains below the solubility limit $\left(\left[\mathrm{O}^{2-}\right]<0.5 \mathrm{~mol} \%\right.$ in $(\mathrm{Li}-\mathrm{Na}-$ $\mathrm{K}_{2} \mathrm{CO}_{3}$ [7]) in the molten carbon-carbonate slurry. This step is suggested to occur rapidly regardless of $\mathrm{CO}_{2}$ concentration, and so does not control cell activity. As such, the RDS of this sequence is a previous step (Steps $\mathrm{A}-\mathrm{H}$ ), as the addition of more $\mathrm{CO}_{2}$ facilitates these processes. 
Further, as EIS data acquired on both full-cell [2] and half-cell setups (Figs. 2-3) [4-5] are dominated by the LF contributions associated with mass transport at the anode/WE [7], the RDS is more likely to be a chemical/physical process (Steps A-G) prior to the electrochemical reaction (Step H).

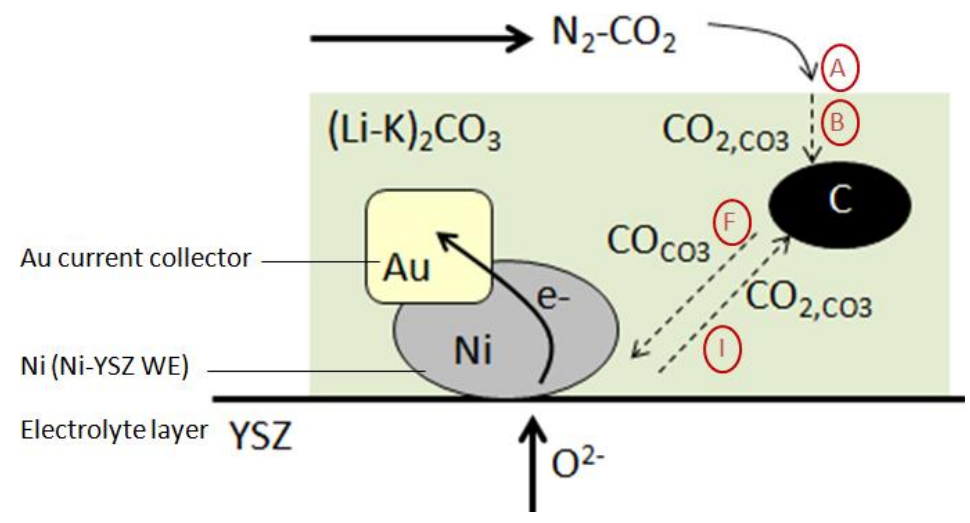

Fig. 10 - Under-saturated melt. Schematic illustrating various processes occurring at the Ni-YSZ electrode in contact with a $\mathrm{CO}_{2}$ under-saturated carbon-carbonate slurry. Where Step $\mathrm{A}$ is the dissolution of $\mathrm{CO}_{2}$ into the molten carbonate solution, Step $\mathrm{B}$ is dissolved $\mathrm{CO}_{2}$ transport to the solid carbon particle, Step F is the dissolved CO transport between carbon particle and Ni-YSZ interface, and Step $\mathrm{I}$ is the dissociation of electrochemically formed $\mathrm{CO}_{2}$ into the under-saturated molten carbonate solution.

In contrast, when cell activity was hindered by the addition of $\mathrm{CO}_{2}$, the situation in Fig. 9(b), the processes occuring at the WE proceed through Steps A-H + Step J. As illustrated in Fig. 11, the final step (Step $\mathrm{J}$ ) involves the desorption of formed $\mathrm{CO}_{2}$, which cannot proceed by dissolving into a saturated molten medium, and so forms a bubble of $\mathrm{CO}_{2}$ in the vicinity of the electrochemically active site. In this scenario, the molten medium has already reached its saturation limit of dissolved $\mathrm{CO}_{2}$ [7], such that additional $\mathrm{CO}_{2}$ may only be released by creating a new gas phase (bubble) at the solid/molten carbonate interface. If the formed $\mathrm{CO}_{2}$ bubble remains near the TPB, this would render 
this site inaccessible to incoming dissolved $\mathrm{CO}$ (Step G). As the concentration of introduced $\mathrm{CO}_{2}$ increases, this would increase the likelihood of these bubbles forming at reactive sites. Loss of reactive sites would cause the cell activity to decline. In this scenario, the RDS would be bubble formation/release from the reactive site (Step J).

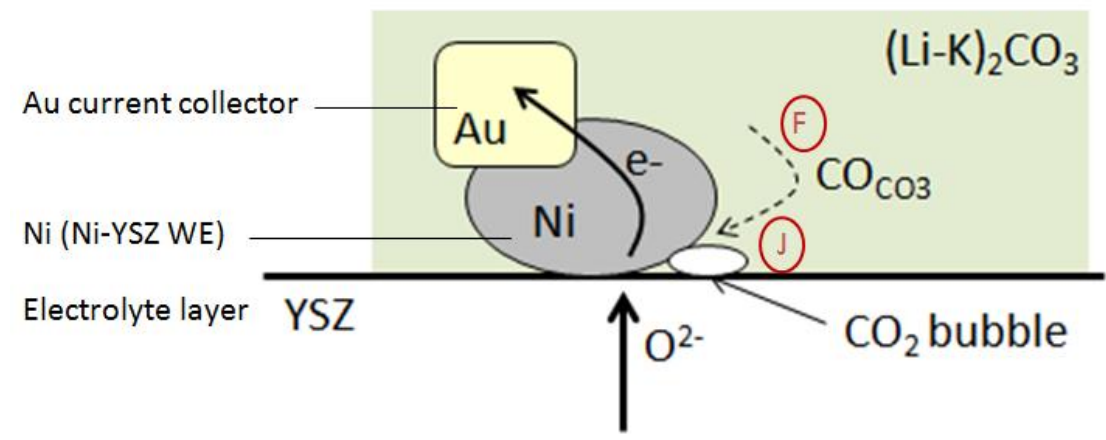

Fig. 11 - Saturated melt. Schematic illustrating various processes occurring at the Ni-YSZ electrode in contact with a $\mathrm{CO}_{2}$ saturated carbon-carbonate slurry. Where Step F is the dissolved CO transport to the Ni-YSZ interface, and Step $\mathrm{J}$ is the formation of a bubble composed of electrochemically formed $\mathrm{CO}_{2}$ between the Ni-YSZ interface and the molten carbonate solution.

Bubble evolution due to carbonate decomposition at elevated temperature $\left(600^{\circ} \mathrm{C}\right)$ has been studied by Kim et al. (2014) [37]. Bubble formation at solid/molten carbonate reactive interfaces has been well illustrated by Chen et al. [38], and the effects of bubble formation at anode reactive sites in a single chamber MCFC-type DCFC have been reported [11]. These single-chamber experiments consisted of a $(38-62 \mathrm{~mol} \% \mathrm{Li}-\mathrm{K})_{2} \mathrm{CO}_{3}$ containing vessel where the carbon fuel was kept separate from the cathode by meshes, which also served as current collectors, and cathode gases $\left(\mathrm{O}_{2}-\mathrm{CO}_{2}\right)$ were introduced at $700-800{ }^{\circ} \mathrm{C}$ [39]. As the concentration of $\mathrm{CO}_{2}$ was increased $\left(\mathrm{CO}_{2}: \mathrm{O}_{2}\right.$ ratio increased), these authors reported the the carbonate melt became saturated, leading to increased 
bubble formation at the anode and decreased current density measured at fixed cell potential $(0.25$ V) [11].

\subsection{Cyclic voltammetry}

As illustrated in Fig. 3(a), a peak was observed in the reverse $(\Delta \mathrm{E}=500 \rightarrow-500 \mathrm{mV}$ vs. Pt/CO$\left.\mathrm{CO}_{2}\right)$ sweep of the $\mathrm{CV}$ curves acquired at $770{ }^{\circ} \mathrm{C}$. This cathodic peak $(\Delta \mathrm{E} \leq 0)$ was observed over the temperature $\left(700-800{ }^{\circ} \mathrm{C}\right)$ and $\mathrm{CV}$ scan rate $(3-15 \mathrm{mV} / \mathrm{s})$ ranges tested, and for the fuels tested. The relationship between cathodic peak current and scan rate, plotted according to the RandlesSevcik equation [4], is illustrated in Fig. 12 at 770 and $800{ }^{\circ} \mathrm{C}$ for carbon black in the absence of the Ni-YSZ anode layer. These peaks were found to be diffusion controlled for fresh and aged (operation time $>48 \mathrm{hrs}$ ) cells. This suggested that the controlling process occurred in the carboncarbonate slurry.

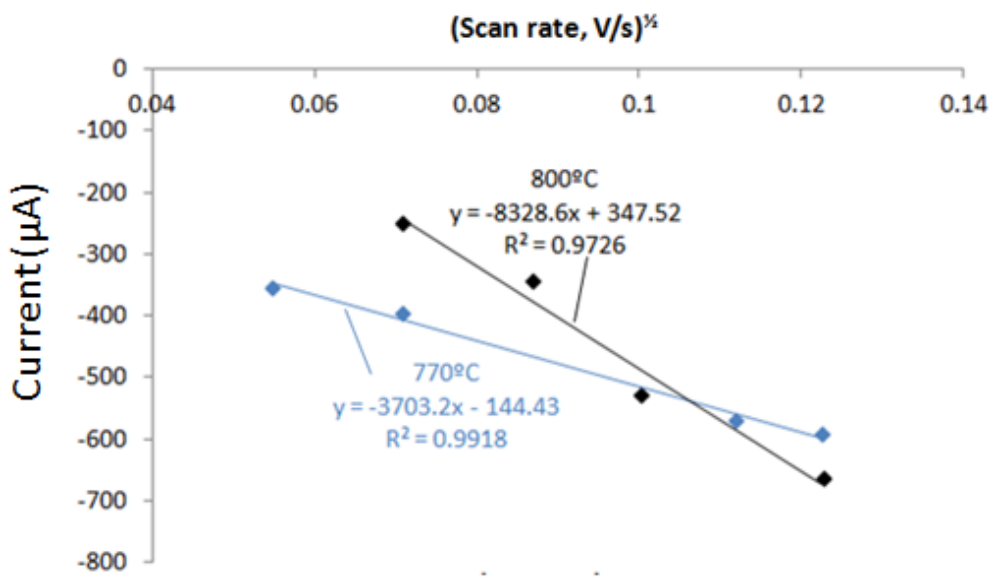

Fig. 12 - Diffusion control. Current at fixed overpotential, as a function of (scan rate) $)^{1 / 2}$, acquired for carbon black in $96-4 \mathrm{~N}_{2}-\mathrm{CO}_{2}$ at 770 and $800{ }^{\circ} \mathrm{C}$ in contact with the YSZ electrolyte (no Ni-YSZ WE).

The reduction potentials of a variety of reactions which may occur in the vicinity of the WE were calculated for $700{ }^{\circ} \mathrm{C}$ using FactSage [4]. Of these, the $\mathrm{K} / \mathrm{K}_{2} \mathrm{O}$ redox couple (Reaction 1) may be 
responsible for the observed cathodic peaks in the CV show in Fig. 3(a), as its reduction potential ($1182 \mathrm{mV}\left(\right.$ vs. $\left.\mathrm{O}_{2}\right)$ at $\left.700{ }^{\circ} \mathrm{C}[40]\right)$ most closely match the half-potential of these peaks ( - $1100 \mathrm{mV}$ vs. Pt/air, $700-800{ }^{\circ} \mathrm{C}$ ), and these reactive species are found in the molten carbonate phase. Potassium (K), and $\mathrm{CO}$, may be formed through the spontaneously interaction of potassium carbonate with carbon (gasification reaction, Reaction 2), while potassium oxide $\left(\mathrm{K}_{2} \mathrm{O}\right)$ may form through the decomposition of carbonate (Reaction 3) [1].

$$
\begin{aligned}
& 2 \mathrm{~K}+\mathrm{CO}_{3}^{2-} \leftrightarrow 2 \mathrm{~K}_{2} \mathrm{O}+\mathrm{CO}_{2}+2 \mathrm{e}^{-} \\
& 2 \mathrm{C}_{(\mathrm{s})}+\mathrm{K}_{2} \mathrm{CO}_{3} \leftrightarrow 2 \mathrm{~K}+3 \mathrm{CO} \\
& \mathrm{K}_{2} \mathrm{CO}_{3} \leftrightarrow \mathrm{CO}_{2}+\mathrm{K}_{2} \mathrm{O}
\end{aligned}
$$

Previous 3-electrode studies employing CV over a similar potential range (Fig. 3) include the observation of diffusion-controlled (i.e., obeys the Randles-Sevcik equation [4]), irreversible peaks in the cathodic sweep for monolithic graphite immersed in $(\mathrm{Li}-\mathrm{K})_{2} \mathrm{CO}_{3}$ under $\mathrm{CO}_{2}$ at $700{ }^{\circ} \mathrm{C}$ (Table 1) [7]; reported curves resemble that shown in Fig. 3(a). These authors attributed these peaks to the reduction of $\mathrm{CO}_{2}$ under cathodic $(\mathrm{E}<\mathrm{OCP})$ conditions [7]. More recently, researchers at Harbin Engineering University (PR China) have reported CVs acquired using Au [17, 20] and Ag [18] electrodes immersed in $(\mathrm{Li}-\mathrm{K})_{2} \mathrm{CO}_{3}$ under $\mathrm{N}_{2}$ between 600 and $750{ }^{\circ} \mathrm{C}$ (Table 1). Under these conditions, no peaks were observed $[17,18,20]$ (vs. Fig. 3(a)). Additionally, the addition of $0.1 \mathrm{~g}$ $\mathrm{NiO}$ to $100 \mathrm{~g} \mathrm{CO}_{3}$ did not give rise to $\mathrm{Ni} / \mathrm{NiO}$ peaks in $\mathrm{CV}$ curves acquired for a $\mathrm{Au}$ electrode at $750^{\circ} \mathrm{C}$ under $\mathrm{N}_{2}$ [17] (vs. Fig. 2(a)). However, MCFC-type DCFC 3-electrode setups (Table 1) have been employed to identify the redox couples of other additives, including $\mathrm{SiO}_{2}$ [21], $\mathrm{CeO}_{2}$ [18], and various sulphur-containing compounds (e.g., $\mathrm{K}_{2} \mathrm{~S}$ ) [20], through the identification of CV peaks. 


\subsection{Coals}

The use of anthracite coal-based fuels have previously been shown to give relatively limited performance in SOFC-type [3], MCFC-type DCFC [6, 11] and HDCFC configurations [3, 41, 42]. Although, anthracite has been reported to generate lower overpotentials than graphite, demonstrating better performance, in both dispersed and monolithic fuel distribution configurations, in single-chamber MCFC-type DCFCs (Table 1) [11]. As shown in Table 2, de-mineralized anthracite samples (AIII-MD, AIII-C) exhibited poor performance (low current at fixed overpotential) at $800{ }^{\circ} \mathrm{C}$ in $96-4 \mathrm{~N}_{2}-\mathrm{CO}_{2}$, with bituminous coal showing the highest performance, as has been reported elsewhere [3, 6, 41, 42].

Differences between the HDCFC performances of coals of different rank (anthracite vs. bituminous coal) may arise from a variety of factors. Bituminous coals usually have lower carbon content and calorific value, which can be disadvantageous towards performance in DCFCs, but on the other hand they usually have higher oxygen [3] and hydrogen [11] contents, exhibit lower crystallinity [10], which improve the reactivity of the coal and, therefore, DCFC performance. Moreover, both bituminous and anthracite coals have mineral matter content, with a percentage and composition that can vary a great deal depending on their origin, the exploitation grade of the basin and the different cleaning and coal preparation processes performed after mining and prior to coal delivery to the market [43]. In the case of the mineral matter present in the coals studied in this work (i.e. BII and AIII), in both cases there are $\mathrm{Al}$ and Si present, typical of most coals, which has been shown to be disadvantageous towards performance in MCFC-type DCFCs when present as $\mathrm{Al}_{2} \mathrm{O}_{3}$ and $\mathrm{SiO}_{2}$ [9]. It should be noted that coal ash fraction elemental evaluation [28] did not allow the speciation of elements (e.g., $\mathrm{Al}, \mathrm{Si}$ ) to be determined. In contrast, bituminous coal employed contained a higher Fe content (12\% vs. $5 \%$ in AIII coal), which can be beneficial for the electrochemical behaviour [9]. 
Current at fixed overpotential of anthracite coal samples (AIII, AIII-MD and AIII-C) varied with ash fraction as determined by proximate analysis (Table 2). The presence of clay and mineral components, kaolin, montmorillonite and alumina, in the ash fraction of coal have been shown to promote MCFC-type DCFC performance when combined with graphite [21]. The removal of these catalytic mineral components, including Fe [9], such as through demineralization [10], may result in decreased performance, as observed for the HDCFC performances of demineralized anthracite (AIII-MD and AIII-C, Table 2 and [28]). Additionally, carbonization (e.g., AIII-C) changes the properties of the coal and so electrochemical performance (Table 2), as seen in other 3-electrode MCFC-type DCFC studies contrasting the performance of coal and coal chars (i.e., carbonized coal samples) $[6,10,15,16]$.

The current at fixed overpotential of the four fuels exhibiting higher performance (Table 2), including carbon black, anthracite (AIII) and bituminous coals (B-I-MD, B-II), were examined as a function of their chemical compositions (ultimate analysis). As shown in Fig. 13, higher activity in a half-cell configuration tended to be associated with lower carbon content, but higher O/C ratios and hydrogen content. Both $\mathrm{O} / \mathrm{C}$ ratio and hydrogen content are associated with the presence of functional groups at the carbon surface [8]. 

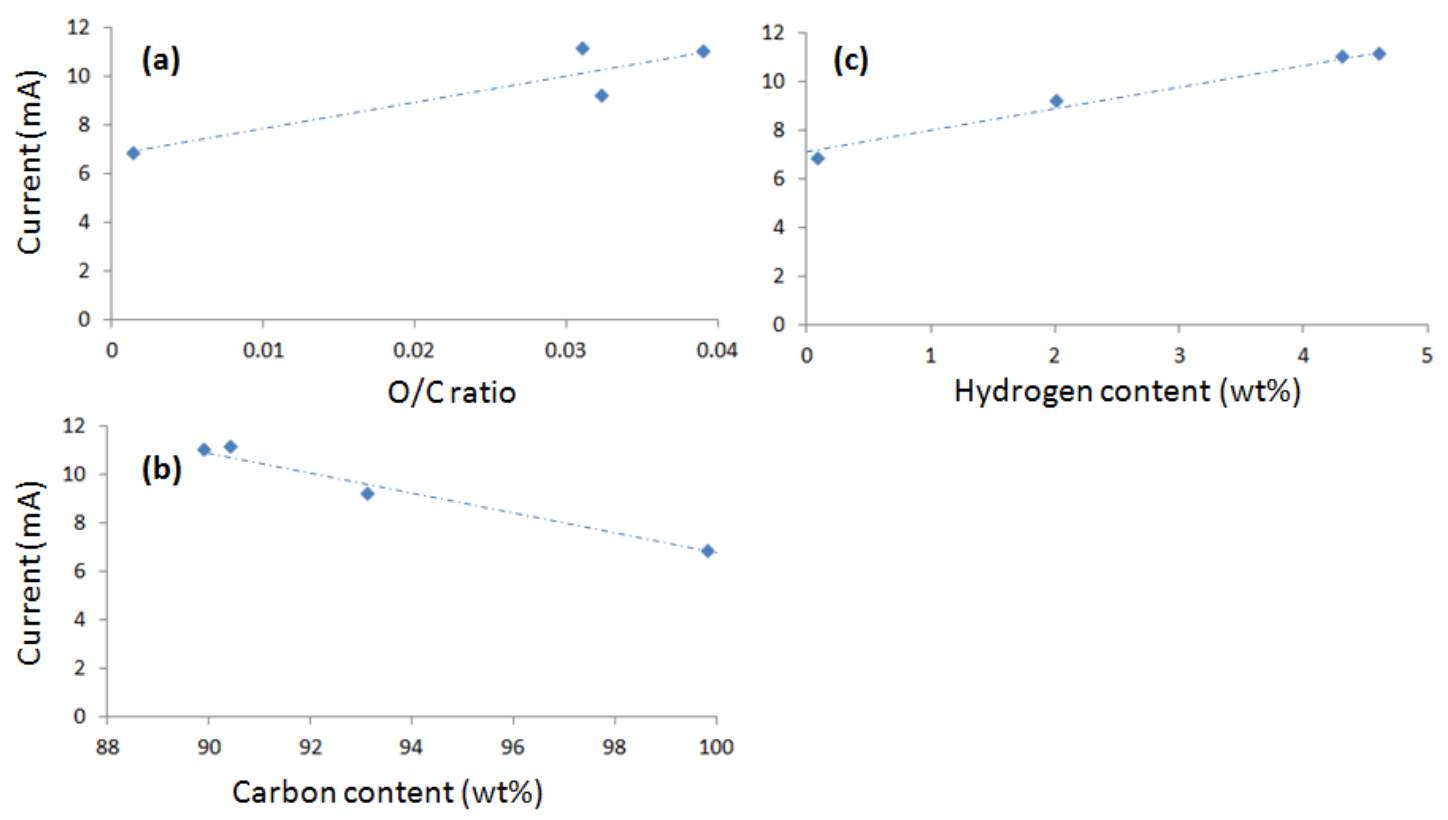

Fig. 13 - Coal properties. From CVs acquired at $800{ }^{\circ} \mathrm{C}$ in $96-4 \mathrm{~N}_{2}-\mathrm{CO}_{2}$, current at fixed overpotential $(\eta=500 \mathrm{mV})$ as a function of (a) O/C ratio, (b) carbon, and (c) hydrogen content, determined by ultimate analysis (Table 2).

High rank coals [43] and carbon black acetylene [27] consist primarily of carbon ( $100 \mathrm{wt} \% \mathrm{C})$, such that for other elements to be included in the compositional mix, such as oxygen and hydrogen, carbon content must decrease. Functional groups, especially oxygen surface groups (i.e., $\mathrm{C}=\mathrm{O}$, $\mathrm{COOH}, \mathrm{C}-\mathrm{OH}$, etc.) are linked to the carbonaceous structure with labile bonds. Therefore, they evolve/desorb easily with an increase in temperature, leaving active sites (un-saturated sites) very liable for further chemical reactions, including carbon gasification [44, 45]. Presence of these surface functional groups has been shown to strongly influence the reactivity of carbon fuels at DCFC anodes in molten hydroxide [46], molten carbonate [8-9, 17], and solid oxide electrolyte DCFCs [47-49]. As such, higher O/C ratio and hydrogen content are expected to be associated with higher loading of reactive surface functional groups, the presence of which promotes activity in the vicinity of the WE, generating larger currents at fixed overpotential. 
Ultimate analysis of treated coals carried out following electrochemical testing evidenced the loss of carbon and hydrogen, and enrichment in oxygen content (Fig. 14). Nitrogen and sulphur contents remained largely unchanged $( \pm 0.5 \mathrm{wt} \%)$. This suggested the transfer of oxygen species to the carbon surface, and the consumption of carbon, consistent with Step D in the proposed reaction sequence, during electrochemical testing in a half-cell setup.
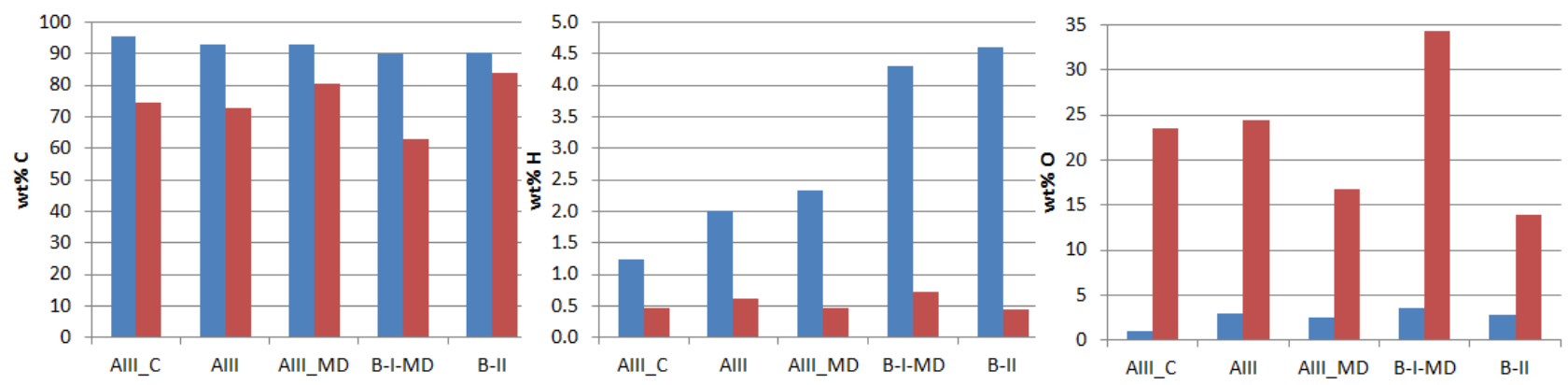

Fig. 14 - Changing coal properties. From ultimate analysis (dry, ash-free basis, wt $\%$ daf), carbon, hydrogen and oxygen contents prior to ( $\mathbf{\square}$, Table 2) and following ( $\mathbf{a})$ electrochemical testing in a half-cell setup.

\subsection{Sweep gas: $\mathrm{N}_{2}-\mathrm{CO}_{2}$ and $\mathrm{CO}-\mathrm{CO}_{2}$}

Relatively few studies have examined the dependence of DCFC performance on $\mathrm{CO}_{2}$ content in mixed inert (e.g., $\left.\mathrm{N}_{2}\right)-\mathrm{CO}_{2}$ atmospheres [2, 4, 6, 50]. Similarly, investigations including the introduction of CO over a carbon bed, such as illustrated in Fig. 7, are relatively limited [5, 25, 51]. Siengchum et al. (2012) reported on a SOFC-type DCFC consisting of coconut biochar in contact with a Ag-impregnated Ni-YSZ anode $\left(750^{\circ} \mathrm{C}\right)$ under $7.4 \% \mathrm{CO}, 8.6 \% \mathrm{CO}_{2}$ or pure $\mathrm{He}$ [51]. More recently, Werhahn et al. (2013) have shown the effects of anode sweep gas $\left(\mathrm{CO}, \mathrm{CO}_{2}, 50-50 \mathrm{CO}-\right.$ $\mathrm{CO}_{2}$, Ar or $\mathrm{He}$ ) and anode layer catalyst (porous GDC anode vs. dense scandia-doped zirconia (SSZ) electrolyte layer) for carbon black (Printex 90) at $950{ }^{\circ} \mathrm{C}$ [25]. Fig. 7 demonstrates the inclusion of 96-4 $\mathrm{N}_{2}-\mathrm{CO}_{2}$ and 50-50 $\mathrm{CO}-\mathrm{CO}_{2}$ at $700{ }^{\circ} \mathrm{C}$. However, comparison/contrast will be 
drawn here between DCFC operation in an inert gas (e.g., $\mathrm{N}_{2}, \mathrm{He}, \mathrm{Ar}$ ) vs. in the presence of an additional fuel (CO).

Previously reports have found OCV values increased upon inclusion of CO [25, 51]. In contrast, OCP was demonstrated to be lower in the presence of 50-50 CO-CO $($ Fig. 8) although this is likely related to the higher partial pressure of $\mathrm{CO}_{2}$, which causes the magnitude of OCP to decrease (Fig. 9). This effect has been illustrated as a lowered $\mathrm{OCV}$ in $8.6 \% \mathrm{CO}_{2}$ (balance of $\mathrm{He}, 1.06 \mathrm{~V}$ ) (vs. 7.4\% $\mathrm{CO}$ in $\mathrm{He}, \sim 1.1 \mathrm{~V})$ [51] and 50-50 $\mathrm{CO}-\mathrm{CO}_{2}(0.89 \mathrm{~V})$ (vs. dry $\left.\mathrm{CO}, 1.01 \mathrm{~V}\right)$ [25].

Most significantly, prior findings have indicated dramatic changes in current-voltage responses, especially I-V (or CV) curve shape, with inclusion of $\mathrm{CO}$. These include the presence of a large mass transfer limitation at high current densities in the presence of $\mathrm{He}(\mathrm{OCV}=0.79 \mathrm{~V})(\mathrm{vs} .7 .4 \%$ $\mathrm{CO})$ [51], and of an inflection point, or change in slope, at $\sim 0.5 \mathrm{~V}$ in $\mathrm{Ar}(\mathrm{OCV}=0.86 \mathrm{~V})$ over a GDC anode layer (vs. $\mathrm{CO}$ and 50-50 $\mathrm{CO}-\mathrm{CO}_{2}$ ) [25], which are absent upon inclusion of $\mathrm{CO}$. Relative to these changes in I-V curve shape [25, 51], the CV curves shown in Fig. 7 show a much higher degree of resemblance. This may be due to a variety of experimental differences, including the presence of alkali carbonates, which affects CV response [5], anode layer catalyst, which has been shown to affect I-V responses (porous GDC vs. dense SSZ layer) and temperature [25]. Whatever the cause, the similarity illustrated in Fig. 7 is unlikely to arise from limited contribution from the electrochemical oxidation of $\mathrm{CO}$, as was suggested for $\mathrm{I}-\mathrm{V}$ curves acquired in $\mathrm{He}$ and $\mathrm{CO}$ with carbon black in contact with a dense electrolyte layer (SSZ) at $950{ }^{\circ} \mathrm{C}$ [25]. This is as Ni-YSZ, the WE in Fig. 7, has been shown to be a reasonable $\mathrm{CO}$ oxidation catalyst in CO-fueled SOFCs [33]. 


\section{Conclusions}

The processes occurring at the anode of a hybrid direct carbon fuel cell (HDCFC) were investigated in a single-atmosphere 3-electrode half-cell setup. The presence of a Ni-YSZ anode layer was shown to increase cell performance without change recorded to open circuit potential (OCP vs. Pt/air) and activation energy of the processes occurring in the vicinity of the working electrode (WE). Carbon black, treated anthracite and bituminous coals were tested in mixed $\mathrm{N}_{2}-\mathrm{CO}_{2}$ between 700 and $800{ }^{\circ} \mathrm{C}$. Relative to carbon black, treated anthracite tended to give higher magnitude OCP values, which increased with temperature, while bituminous coals showed the highest performance (measured as current at fixed overpotential). Calculated activation energies were $1.2 \pm 0.3 \mathrm{eV}$ for all fuels tested in both $96-4$ vol\% $\mathrm{N}_{2}-\mathrm{CO}_{2}$ and $50-50$ vol\% $\mathrm{CO}-\mathrm{CO}_{2}$

Cell activity, measured by cyclic voltammetry (CV) and electrochemical impedance spectroscopy (EIS), was investigated as a function of $\mathrm{CO}_{2}$ content in mixed $\mathrm{N}_{2}-\mathrm{CO}_{2}$ at fixed temperatures. Two situations were observed: linear and inverse dependence of cell performance on vol\% $\mathrm{CO}_{2}$. Consistent with these situations, a reaction sequence in the vicinity of the WE was proposed, with the oxidation of $\mathrm{CO}$ being the dominant electrochemical reaction. The differences in behavior with variable $\mathrm{CO}_{2}$ were suggested to arise from differences in the rate determining step (RDS) which depended on the level of saturation of dissolved $\mathrm{CO}_{2}$ in the carbon-carbonate slurry. When saturated, the formation of bubbles of $\mathrm{CO}_{2}$ blocking the electrochemically-active sites was proposed. Currents, measured at fixed overpotential, tended to increase with $\% \mathrm{CO}_{2}$ in mixed $\mathrm{N}_{2}-$ $\mathrm{CO}_{2}$ when the carbon-carbonate slurries were under-saturated with $\mathrm{CO}_{2}$, while currents decreased as $\% \mathrm{CO}_{2}$ increased (inverse relationship) when slurries were saturated. 


\section{Acknowledgements}

This work was funded in part by the European Commission Research Fund for Coal and Steel, as the Efficient Conversion of Coal to Electricity - Direct Coal Fuel Cells project, in collaboration with the University of St. Andrews, University of Western Macedonia, and the Spanish Instituto Nacional del Carbón (INCAR). Additional funding was supplied by the Department of Energy Conversion and Storage at the Danish Technical University (DTU)-Risoe Campus. We extend our thanks to M. Nielsen, A. Petersen and F. Vico, as well as to Drs. C. Graves, P. Holtappels, D. Ippolito, M. Mogensen, and S. Veltzé at the DTU Department of Energy Conversion and Storage for all assistance.

\section{References}

1. Deleebeeck L, and Hansen KK. Hybrid direct carbon fuel cells and their reaction mechanisms - a review. J. Solid St. Electrochem. 2014; 18: 861

2. Deleebeeck L, and Hansen KK. HDCFC performance as a function of anode atmosphere $\left(\mathrm{N}_{2}-\mathrm{CO}_{2}\right)$. J. Electrochem. Soc. 2014; 161(1): F33

3. Kaklidis N, Kyriakou V, Garagounis I, Arenillas A, Menéndez JA, Marnellos GE, and Konsolakis M. Effect of carbon type on the performance of a direct and hybrid carbon solid oxide fuel cell. RSC Adv. 2014; 4: 18792

4. Deleebeeck L, Ippolito D, and Hansen KK. Enhancing hybrid direct carbon fuel cell anode performance using $\mathrm{Ag}_{2} \mathrm{O}$. Electrochim. Acta 2014; accepted

5. Deleebeeck L, and Hansen KK. Effect of supplied CO-CO $\mathrm{CO}_{2}$ in the presence of carbon, J. Electrochem. Sci. Tech. 2014; submitted

6. Vutetakis DG, Skidmore DR, and Byker HJ. Electrochemical oxidation of molten carbonatecoal slurries. J. Electrochem. Soc. 1987; 134(12): 3027 
7. Peelen WHA, Olivry M, Au SF, Fehribach JD, and Hemmes K. Electrochemical oxidation of carbon in a 62/38 mol\% Li/K carbonate melt. J. Appl. Electrochem. 2000; 30: 1389

8. Li X, Zhu ZH, De Marco R, Dicks A, Bradley J, Liu S, and Lu GQ. Factors that determine the performance of carbon fuels in the direct carbon fuel cell. Ind. Eng. Chem. Res. 2008; 47: 9670

9. Li X, Zhu Z, De Marco R, Bradley J, and Dicks A. Evaluation of raw coals as fuels for direct carbon fuel cells. J. Power Sources 2010; 195: 4051

10. Li X, Zhu Z, De Marco R, Bradley J, and Dicks A. Modification of coal as a fuel for the direct carbon fuel cell, J. Phys. Chem. A 2010; 114: 3855

11. Predtechensky MR, Varlamov YuD, Ul'yankin SN, and Dubov YD. Direct conversion of solid hydrocarbons in a molten carbonate fuel cell. Thermophys. Aeromech. 2009; 16(4): 601

12. Chen CC, Maruyama T, Hsieh PH, and Selman JR. Wetting behavior of carbon in molten carbonate. J. Electrochem. Soc. 2012; 159(10): D597

13. Ahn SY, Eom SY, Rhie YH, Sung YM, Moon CE, Choi GM, and Kim DJ. Application of refuse fuels in a direct carbon fuel cell system. Energy 2013; 51: 447

14. Ahn SY, Eom SY, Rhie YH, Sung YM, Moon CE, Choi GM, and Kim DJ. Utilization of wood biomass char in a direct carbon fuel cell (DCFC) system. Appl. Energy 2013; 105: 207

15. Eom S, Ahn S, Rhie Y, Kang K, Sung Y, Moon C, Choi G, and Kim D. Influence of devolatilized gases composition from raw coal fuel in the lab scale DCFC (direct carbon fuel cell) system. Energy 2014; 10.1016/j.energy.2014.07.039

16. Rhie Y, Eom S, Ahn S, Choi G, and Kim D. Effect of thermal decomposition products of coal on anodic reactions in direct carbon fuel cells. J. Mech. Sci. Tech. 2014; 28(9): 3807 
17. Wang CW, Liu J, Zeng J, Yin JL, Wang GL, and Cao DX. Significant improvement of electrooxidation performance of carbon in molten carbonates by the introduction of transition metal oxides. J. Power Sources 2013; 233: 244

18. Liu J, Ye K, Cheng K, Wang G, Yin J, and Cao D. The catalytic effect of $\mathrm{CeO}_{2}$ for electrochemical oxidation of graphite in molten carbonate. Electrochim. Acta 2014; 135: 270

19. Liu J, Ye K, Zeng J, Wang G, Yin J, and Cao D. A novel electrolyte composed of carbonate and $\mathrm{CsVO}_{3}-\mathrm{MoO}_{3}$ for electrochemical oxidation of graphite. Electrochem. Commun. 2014; 38: 12

20. Liu J, Ye K, Du M, Yin J, Cao D, and Wang G. Effect of sulfur and its compounds on the performance of graphite electrooxidation in molten carbonate. J. Power Sources 2014; 10.1016/j.jpowsour.2014.10.012

21. Tulloch J, Allen J, Wibberley L, and Donne S, Influence of selected coal contaminants on graphitic carbon electro-oxidation for application to the direct carbon fuel cell. J. Power Sources 2014; 260: 140

22. Allen JA, Tulloch J, Wibberley L, and Donne SW. Kinetic analysis of the anodic carbon oxidation mechanism in a molten carbonate medium. Electrochim. Acta 2014; 129: 389

23. Watanabe H, Furuyama T, and Okazaki K, Enhancing the efficiency of direct carbon fuel cells by bubbling Ar gas in carbon/carbonate slurry. J. Power Sources 2014; 273: 340

24. Dudek M, Sitarz M, and Tomczyk P. Effect of structural properties of carbon-based fuels on efficiency of direct carbon fuel cells. J. Solid St. Electrochem. 2014; 10.1007/s10008-0142442-y

25. Werhahn MG, Schneider O, and Stimming U. Thin film gadolinia doped ceria (GDC) anode for direct conversion of carbon black particles in a single planar SOFC. ECS Trans. 2013; 50(27): 73 
26. Ju H, Eom J, Lee JK, Choi H, Lim TH, Song RH, and Lee J. Durable power performance of a direct ash-free coal fuel cell. Electrochim. Acta 2014; 115: 511

27. Wang MJ, Gray CA, Reznek SA, Mahmud K, and Kutsovsky Y. Carbon Black. Kirk-Othmer Encyclopedia of Chemical Technology 2004; 4: 761-803, John Wiley \& Sons, USA

28. Deleebeeck L, Ippolito D, Arenillas A, Menendez JA, and Hansen KK, Anthracite-fueled hybrid direct carbon fuel cell. Appl. Energy 2014; submitted

29. Lee EK, Chen $\mathrm{HH}$, and Kim YT. Enhancing Ni anode performance via $\mathrm{Gd}_{2} \mathrm{O}_{3}$ addition in molten carbonate-type direct carbon fuel cell. Intl. J. Hydrog. Energy 2014; 10.1016/j.ijhydene.2014.03.180

30. Giddey S, Kulkarni A, Munnings C, and Badwal SPS. Performance evaluation of a tubular direct carbon fuel cell operating in a packed bed of carbon. Energy 2014; 10.1016/j.energy.2014.01.105

31. Gur TM, Critical review of carbon conversion in "Carbon Fuel Cells". Chem. Rev. 2013; 113: 6179

32. Leonide A, Hansmann S, Weber A, and Ivers-Tiffee E. Performance simulation of current/voltage-characteristics for SOFC single cell by means of detailed impedance analysis. J. Power Sources 2011; 196: 7343

33. Utz A, Leonide A, Weber A, and Ivers-Tiffee E. Studying the $\mathrm{CO}-\mathrm{CO}_{2}$ characteristics of SOFC anodes by means of patterned Ni anodes. J. Power Sources 2011; 196: 7217

34. Yurkiv V, Starukhin D, Volpp HR, and Bessler WG. Elementary reaction kinetics of the $\mathrm{CO} / \mathrm{CO}_{2} / \mathrm{Ni} / \mathrm{YSZ}$ electrode. J. Electrochem. Soc. 2011; 158(1): B5

35. Zhang H, Chen J, and Zhang J. Performance analysis and parametric study of a solid oxide fuel cell fueled by carbon monoxide. Intl. J. Hydrog. Energy 2013; 38: 16354 
36. Cooper JF, and Selman JR. Analysis of the carbon anode in direct carbon conversion fuel cells. Intl. J. Hydrog. Energy 2012; 37: 19319

37. Kim M, Kim K, Hwang M, Kim K, and Song J. Evaluation of bubble suspension behavior in electrolyte melts. Kor. J. Chem. Eng. 2014; 31(2): 201

38. Chen CC, Maruyama T, Hsieh PH, and Selman JR. The reverse Boudouard reaction in direct carbon fuel cells. ECS Trans. 2010; 28(30): 227

39. Predtechenskii MR, Varlamov YD, and Ul'yankin SN. Specific characteristics of molten carbonate fuel cell in realization of electrochemical coal oxidation. Russ. J. Electrochem. 2010; 46(8): 871

40. FactSage 6.4, CRCT - ThermFact Inc. \& GTT-Technologies, http://www.factsage.com/, accessed September 2014

41. Jiang C, Ma J, Arenillas A, and Irvine JTS. Hybrid direct carbon fuel cells with different types of mineral coal. ECS Trans. 2013; 57(1): 3013

42. Chien AC, Arenillas A, Jiang C, and Irvine JTS. Performance of direct carbon fuel cells operated on coal and effect of operation mode. J. Electrochem. Soc. 2014; 161(5): F588

43. Pajares JA, and Diez MA. Coal and Coke. Elsevier Reference Module in Chemistry, Molecular Sciences and Chemical Engineering. Reedijk J. ed. Elsevier, Waltham, MA, USA 2014; 10.1016/B978-0-12-409547-2.10968-0

44. Stanmore BR, Brilhac JF, and Gilot P. The oxidation of soot: a review of experiments, mechanisms and models. Carbon 2001; 39: 2247

45. Carlsson PA. Detailed modeling of carbon oxidation. J. Phys. Chem. C 2012; 116: 9063

46. Nunoura T, Dowaki K, Fushimi C, Allen S, Meszaros E, and Antal MJ. Performance of a first-generation aqueous-alkaline biocarbon fuel cell. Ind. Eng. Chem. Res. 2007; 46: 734 
47. Li C, Shi Y, and Cai N. Mechanism for carbon direct electrochemical reactions in a solid oxide electrolyte direct carbon fuel cell. J. Power Sources 2011; 196: 754

48. Dudek M, Tomczyk P, Socha R, Skrzypkiewicz M, and Jewulski J. Biomass fuels for direct carbon fuel cell with solid oxide electrolyte. Intl. J. Electrochem. Sci. 2013; 8: 3229

49. Dudek M, Tomczyk P, Socha R, and Hamaguchi M. Use of ash-free "Hyper-coal" as a fuel for a direct carbon fuel cell with solid oxide electrolyte. Intl. J. Hydrog. Energy 2014; 39: 12386

50. Rady AC, Giddey S, Kulkarni A, Badwal SPS, and Bhattacharya S. Degradation mechanism in a direct carbon fuel cell operated with demineralized brown coal. Electrochim. Acta 2014; 143: 278

51. Siengchum T, Guzman F, and Chuang SSC. Analysis of gas products from direct utilization of carbon in a solid oxide fuel cell. J. Power Sources 2012; 213: 475 